\title{
COMMUNICATIONS
}

\section{ACTION OF DIAMOX AND AMMONIUM CHLORIDE ON FORMATION OF AQUEOUS HUMOUR*}

\author{
BY
}

\author{
MAURICE E. LANGHAM AND PATIENCE M. LEE \\ From the Ophthalmological Research Unit (Medical Research Council), \\ Institute of Ophthalmology, University of London
}

THE investigation was undertaken to establish the cause of the decrease in intra-ocular pressure induced in normal rabbits by 2-acetylamino-1, 3, 4 thiadiazole 5-sulphonamide $\dagger$, an inhibitor of the enzyme carbonic anhydrase. At the same time, it was hoped that a comparison of these results with the known ability of Diamox to reduce the intra-ocular pressure in glaucomatous patients for extensive periods would help in assessing whether the intraocular dynamics of normal and pathological eyes are affected in a similar manner and to a comparable extent.

The lowering of the intra-ocular pressure by Diamox has led to the suggestion that the enzyme carbonic anhydrase is essential to the formation of the aqueous humour, and this idea has found expression in the hypothesis that the reduction of the intra-ocular pressure by Diamox is due to an inhibition of secretion across the blood-aqueous barrier (Becker, 1955a; Friedenwald, 1955a, b). This view had its origin in the studies of Friedenwald and Stiehler (1938) on the transfer of acidic and basic dyes across the epithelial layers of the ciliary processes. Friedenwald (1949) suggested that hydroxyl ions were secreted into the aqueous humour, and that an excess of bicarbonate was produced from the reaction of the hydroxyl ions with carbonic acid. This view was supported by Kinsey (1950), who observed in rabbits that the concentrations of hydroxyl and bicarbonate ions in the aqueous humour exceeded those in the plasma. The participation of carbonic anhydrase in this secretory activity was supported by the reports of the presence of the enzyme in extracts of the iris and the ciliary processes (Wistrand, 1951; Kauth and Sommer, 1953; Green, Capper, Bocher, and Leopold, 1954; Gloster and Perkins, 1955a).

Experiments designed to test either this hypothesis or alternative explanations of the action of Diamox in reducing the intra-ocular pressure have been reported by several investigators (Becker, 1955a, b, 1956; Becker and Constant, 1955; Green, Bocher, and Leopold, 1955; Langham and Lee, $1955 \mathrm{a}, \mathrm{b}, \mathrm{c})$. There is general agreement that the reduction in the intraocular pressure is accompanied by a decreased rate of formation of aqueous humour, but the means by which this is brought about is still unresolved.

- Received for publication November 13, 1956. † Diamox, Lederle Laboratories. 
Becker (1955a, b, 1956) and Becker and Constant (1955) reported that their experimental results were consistent with the view that Diamox lowers the intra-ocular pressure by directly inhibiting the secretion of aqueous humour and in particular the transfer of excess bicarbonate into the aqueous humour. However, evidence that the ratio of the concentrations of bicarbonate between the aqueous humour and the blood was unchanged in animals given Diamox, in spite of the absolute decrease in the concentrations, led Langham and Lee $(1955 \mathrm{a}, \mathrm{b})$ to question whether the production of excess bicarbonate in the eye in fact depends on a secretory mechanism involving carbonic anhydrase.

In the present study three aspects of this problem have been considered. First, the $p \mathrm{H}$ and the distribution of bicarbonate ions between the blood and the aqueous humour before and after the administration of Diamox have been determined. In particular, attention has been focused on possible differences between the composition of the fluids in transient and steadystate conditions. This was undertaken in view of the rapid decrease in the intra-ocular pressure that takes place immediately after giving Diamox (Becker, 1955a; Gloster and Perkins, 1955). Similar studies were made on animals with the renal arteries tied off and on animals given ammonium chloride in view of the interesting observations of Becker (1955a) that neither the administration of ammonium chloride nor nephrectomy made animals unresponsive to Diamox. Technically, this problem involved measurements of $p \mathrm{H}$ by the glass electrode technique and the analysis of total carbon dioxide in small volumes of fluid. Previously published papers relevant to this question include those of Kinsey (1950), Green, Bocher, and Leopold (1955), and Becker (1955). Kinsey (1950) measured the $p \mathrm{H}$ of the aqueous humour and the plasma by a dye technique, and the total carbon dioxide by the manometric technique of van Slyke (1926), and reported that the $p \mathrm{H}$ and the total concentration of carbon dioxide in the aqueous humour exceeded that in the plasma. Green and others (1955) reported that Diamox did not affect the concentration of total carbon dioxide in either the aqueous humour or the blood, and Becker (1955b) reported that Diamox reduced the concentration of total carbon dioxide in the aqueous humour but not in the blood. It is not at all evident from these last two papers why there should be a discrepancy between the results, but it is hoped that the more detailed approach used in the present study has avoided the errors inherent in the techniques used in previous studies. In particular, care has been taken to analyse whole arterial blood rather than plasma derived from a mixed arterial-venous sample obtained by cardiac punctures.

The second aspect of the problem concerns the effect of Diamox and ammonium chloride on the rate of formation of aqueous humour. For this purpose, fluorescein has been used as the test substance, and the concentration of fluorescein in the anterior chamber has been continuously recorded by a technique described in an earlier paper (Langham and Wybar, 1954). 
The use of fluorescein to measure changes in the rate of formation of the aqueous humour by observing the time taken for the dye to pass through the posterior chamber was first suggested by Linnér and Friedenwald (1954). Since then the method has been employed in several studies (Becker, 1955c; Kornblueth and Linnér, 1955; Langham and Lee, 1955a, b). That fluorescein may be used in this way has found confirmation in a separate study (Langham and Wood, 1956).

The third aspect deals with the changes in the intra-ocular pressure in animals given Diamox or ammonium chloride during the period leading to a new condition of steady-state. This has assumed an increasing importance in view of observations that the effect of Diamox on the rate of formation of aqueous humour and distribution of bicarbonate ions across the bloodaqueous barrier was minimal in conditions of steady-state.

\section{Methods}

Adult rabbits of both sexes were used. They were fed Diet 18 pellets (Associated London Flour Millers), water ad lib., and hay once a week. Samples of aqueous humour were taken after instilling a 1 per cent. solution of pantocaine into the conjunctival sac. All samples of aqueous humour were tested for the presence of protein by the addition of an equal volume of a solution of 8 per cent. (w/v) trichloroacetic acid, and the results were rejected if more than the normal faint clouding was observed. Blood samples were removed from the heat-dilated median artery of the ear. The Diamox for injections was prepared as a 10 per cent. solution of the sodium salt. Intravenous injections of fluorescein were made, using a 10 per cent. solution of the sodium salt.

The rate of accumulation of fluorescein in the anterior chamber was studied in rabbits anaesthetized with urethane $(1.75 \mathrm{~g}$. $/ \mathrm{kg}$. body weight). Urethane in a 25 per cent. solution was slowly injected intravenously and $15 \mathrm{~min}$. later $1.0 \mathrm{ml}$. of a 10 per cent. solution of sodium fluorescein was injected intravenously into the marginal ear vein within a period of $10 \mathrm{sec}$.

The ascorbic acid was dissolved in water, partially neutralized with a solution of sodium hydroxide to a $p \mathrm{H}$ of 6.5 to $7 \cdot 2$ and made up to an isotonic concentration. Raised concentrations of ascorbic acid in the plasma were maintained by an initial intravenous injection followed by hourly intramuscular injections for 6 hrs. A period of $6 \mathrm{hrs}$ is sufficient to allow a steady-state to be reached in the aqueous humour to within a few per cent. (Bárány and Langham, 1955).

Analytical.-There are both theoretical and practical reasons for using whole blood rather than plasma to determine the $p \mathrm{H}$ and the concentration of total carbon dioxide in the plasma. Thus whole blood may be analysed immediately, and provided the haemoglobin and water content are known. the plasma values may be derived directly from the nomograms of van Slyke and Sendroy (1928). In contrast, to obtain plasma, the blood has first to be centrifuged, which involves difficulties in maintaining the composition and $p \mathrm{H}$ constant. Consequently, all determinations were made on freshly withdrawn samples of arterial blood. To enable the $p \mathrm{H}$ and the total carbon dioxide measurements to be made on the aqueous humour of each rabbit, samples from the two eyes were withdrawn into the same syringe and the pooled sample analysed immediately. In this way it was possible to take duplicate determinations of the $p \mathrm{H}$ and the total carbon dioxide on each sample. The alternative method of using the aqueous humour of one eye for both analyses was rejected in view of the larger errors involved in making analyses on volumes of less than 0.15 to $0.20 \mathrm{ml}$. 
The $p \mathrm{H}$ of the blood and the aqueous humour was estimated using a Cambridge model $p \mathrm{H}$ meter with a micro glass electrode and cell. Dead space in the cell was reduced to approximately $0.75 \mathrm{ml}$., and the sample was introduced from a syringe directly into the chamber through a capillary tube connexion. The cell was immersed in a saturated solution of $\mathrm{KCl}$ which acted as a water bath as well as a junction to the calomel half-cell.

To obtain stable $p \mathrm{H}$ readings on the small samples of aqueous humour, it was found imperative to dry the micro-cell and prevent any mixing of the aqueous humour in the cell with the $\mathrm{KCl}$ in the connecting capillary. The glass electrode cannot, however, be dried, and it is important to wash the electrode with $\mathrm{CO}_{2}$-free glass-distilled water of $p \mathrm{H} \mathrm{7.0} \mathrm{in} \mathrm{view} \mathrm{of} \mathrm{the} \mathrm{limited} \mathrm{buffering} \mathrm{power} \mathrm{of} \mathrm{the} \mathrm{aqueous} \mathrm{humour.} \mathrm{The} \mathrm{temperature}$ correction factor was estimated separately (see Results). In these conditions the $p \mathrm{H}$ of the blood and the aqueous humour was found to remain unchanged for at least $3 \mathrm{~min}$. $p \mathrm{H}$ readings were taken within 1 to $2 \mathrm{~min}$. of removing the sample from the animal. Standard buffers of known $p \mathrm{H}$ were run at the beginning and end of each run of readings.

The total $\mathrm{CO}_{2}$ of the blood and the aqueous humour was determined by the manometric technique of van Slyke and Neill (1924). To derive the concentration of total $\mathrm{CO}_{2}$ in the plasma, use was made of the nomogram compiled by van Slyke and Sendroy (1928); this relates $p \mathrm{H}$ to the oxygen capacity of the blood and gives the factor by which the $\mathrm{CO}_{2}$ content of whole blood may be converted to plasma $\mathrm{CO}_{2}$. For these calculations the oxygen capacity of rabbit blood was determined separately on a group of six animals, and a mean value of $19 \cdot 1 \pm 0.3 \mathrm{ml} . / 100 \mathrm{ml}$. was recorded. The conversion factor changes less than 1 per cent. for a change in the oxygen capacity of from 19 to 20 vols per cent.

The concentrations of bicarbonate and $\mathrm{CO}_{2}$ were calculated from the total $\mathrm{CO}_{2}$ concentration and the blood $p \mathrm{H}$ by using the Henderson-Hasselbach equation, In this equation the $p \mathrm{~K}$ for the bicarbonate system in blood was taken as 6.10 and in aqueous humour as 6.13. The latter figure is that given by Warburg (1922) for a protein-free bicarbonate solution containing $150 \mathrm{~m}$. moles $\mathrm{NaCl}$ per $\mathrm{kg}$. $\mathrm{H}_{2} \mathrm{O}$, which is an equivalent ionic concentration to the aqueous humour.

The $\mathrm{CO}_{2}$ tension in the blood and the aqueous humour was calculated from the $\mathrm{CO}_{2}$ concentration; $\mathrm{mM}\left(\mathrm{H}_{2} \mathrm{CO}_{3}\right)=\frac{1,000 \alpha \mathrm{CO}_{2}}{22 \cdot 4} \times \frac{p \mathrm{CO}_{2}}{760}$ where $\alpha \mathrm{CO}_{2}$ represents the ml. $\mathrm{CO}_{2}$ dissolved per g. $\mathrm{H}_{2} \mathrm{O}$ at $760 \mathrm{~mm}$., and $p \mathrm{CO}_{2}$ represents the tension in $\mathrm{mm}$. $\mathrm{Hg}$. The value of $\mathrm{CO}_{2}$ substituted in the above equation was 0.533 (van Slyke, Sendroy, Hastings, and Neill, 1928); the equation simplifies to $\mathrm{mMH}_{2} \mathrm{CO}_{3} / \mathrm{kg} . \mathrm{H}_{2} \mathrm{O}=0.0315 p \mathrm{CO}_{2}$.

The mean water content of the aqueous humour was taken as 99 per cent., and in a series of ten determinations the water content of whole blood was found to be $82 \cdot 3 \pm 0 \cdot 30$ per cent. Direct determination of the concentrations of total carbon dioxide in the plasma agreed with the values derived from the analysis of whole blood.

Ascorbic acid in samples of aqueous humour were analysed immediately after withdrawal by the procedure previously described (Bárány and Langham, 1955).

The concentration of sodium in the aqueous humour and the plasma was determined by the standard flame photometric technique by the procedure previously described (Langham and Taylor, 1956).

Measurement of the Intra-Ocular and Blood Pressures.-Rabbits were anaesthetized by the intraperitoneal injection of a 25 per cent. solution of urethane $(1.75 \mathrm{~g} . / \mathrm{kg}$.). The femoral artery on one side was cannulated for the blood pressure record. The intraocular pressure was measured by the technique of Greaves and Perkins (1952).

Measurement of the intra-ocular pressure in conscious animals was made by a tonometric technique using a standard Schiötz $X$ tonometer. The animal was placed in a canvas bag tied around the neck to restrain undue movement and one drop of pantocaine ( 1 per cent.) was placed in each eye. This was washed off almost immediately with saline to prevent corneal drying. Two readings were recorded on each eye. 


\section{Results}

Chemical Studies.-The $p \mathrm{H}$ of the blood and the aqueous humour were measured at room temperature and the values corrected to body temperature. Rosenthal (1948) determined the $p \mathrm{H}$-temperature coefficient for whole rabbit blood and reported a value of $0.0147 \pm 0.00020 \mathrm{pH}$ units per ${ }^{\circ} \mathrm{C}$.; von Sallman and di Grandi (1946) reported the $p \mathrm{H}$ of the aqueous humour of 24 rabbits to be 7.53 at $36.5 \mathrm{C} .^{\circ}$ and the $p \mathrm{H}$ of the aqueous humour of ten rabbits to be 7.63 at $23^{\circ} \mathrm{C}$. In the present study the $p \mathrm{H}$-temperature coefficients of freshly-drawn arterial blood and of the aqueous humour of twelve conscious rabbits were determined. The mean value for blood was $0.0147 \pm 0.00020 \mathrm{pH}$ units per ${ }^{\circ} \mathrm{C}$. and for the aqueous humour it was $0.0064 \pm 0.00025 p \mathrm{H}$ units per ${ }^{\circ} \mathrm{C}$. Throughout the temperature range studied, namely 15 to $37.5^{\circ} \mathrm{C}$., the temperature coefficients for blood and for aqueous humour were found to be constant and the $p \mathrm{H}$ effect fully reversible. In the following results the $p \mathrm{H}$ of the blood and the aqueous humour have been corrected by the use of these factors; the mean temperature of the aqueous humour has been taken as $36.5^{\circ} \mathrm{C}$. (von Sallman and di Grandi, 1946).

The mean $p \mathrm{H}, \mathrm{CO}_{2}$ tension, and concentrations of total $\mathrm{CO}_{2}$ and bicarbonate in the arterial plasma and aqueous humour of conscious rabbits are recorded in Table I. The concentrations of bicarbonate and hydroxyl ions in the aqueous humour exceeded those in the arterial plasma and are in general agreement with the observations of Kinsey (1950). In addition, the calculated value for the $\mathrm{CO}_{2}$ tension in the aqueous humour agreed with the mean value of $35.1 \mathrm{~mm}$. $\mathrm{Hg}$ reported by Pierce, Friedenwald, and Freeman (1933). These workers introduced a bubble of nitrogen into the anterior chamber of dogs, and analysed the $\mathrm{CO}_{2}$ content in samples of the bubble after increasing time intervals. The observation that the $\mathrm{CO}_{2}$ tension in the blood and the aqueous humour are approximately equal was to be expected in view of the relatively small molecular size, the lipoid solubility of carbon dioxide, and the ease with which lipoid-soluble molecules penetrate the blood aqueous barrier (Ross, 1951; Langham, 1955a).

The effect of Diamox on the composition of arterial blood and aqueous

TABLE I

COMPOSITION OF ARTERIAL PLASMA AND AQUEOUS HUMOUR OF NORMAL CONSCIOUS RABBITS

Plasma values calculated from analysis on arterial blood

Concentrations expressed in $\mathrm{mM} / \mathrm{kg} \cdot \mathrm{H}_{2} \mathrm{O}$ and $\mathrm{CO}_{2}$ tension in $\mathrm{mm} . \mathrm{Hg}$

\begin{tabular}{|c|c|c|c|c|c|c|}
\hline & & & Plasma & Aqueous Humour & $\mathbf{A q}-\mathbf{P l}$ & $\mathrm{Aq} / \mathrm{Pl}$ \\
\hline $\begin{array}{l}p \mathrm{H} \\
\mathrm{H}^{+} \ldots \\
\mathrm{Total}^{\mathrm{CO}_{2}} \\
\mathrm{HCO}^{-}{ }_{3} \\
\mathrm{pCO}_{2}\end{array}$ & $\begin{array}{l}\cdots \\
\cdots \\
\cdots \\
\cdots \\
\cdots\end{array}$ & $\begin{array}{l}\ldots \\
\cdots \\
\cdots \\
\cdots \\
\cdots\end{array}$ & $\begin{array}{c}7 \cdot 43 \pm 0 \cdot 012(12) \\
3.71 \times 10^{-8} \\
24 \cdot 2 \pm 1 \cdot 05(12) \\
23 \cdot 1 \pm 1 \cdot 07(12) \\
35 \pm 1 \cdot 2(12)\end{array}$ & $\begin{array}{c}7 \cdot 60 \pm 0 \cdot 020(12) \\
2 \cdot 51 \times 10^{-8} \\
31 \cdot 6 \pm 1 \cdot 19(12) \\
30 \cdot 5 \pm 1 \cdot 20(12) \\
35 \pm 1 \cdot 2(12)\end{array}$ & $\begin{array}{c}0.17 \pm 0.02 \\
-1.20 \times 10^{-8} \\
7.4 \pm 0.96 \\
7.4 \pm 0.90 \\
0.0 \pm 0.8\end{array}$ & $\begin{array}{l}\overline{0.68} \\
1 \cdot 31 \\
1 \cdot 32 \\
1 \cdot 00\end{array}$ \\
\hline
\end{tabular}


humour was studied approximately 15 and 150 minutes after an intravenous injection. The time interval of 15 minutes was chosen in view of the known ability of Diamox given intravenously to cause a significant reduction in the intra-ocular pressure within this time (Gloster and Perkins, 1955b). The period of 150 minutes was based on preliminary experiments which showed that the fall in the $p \mathrm{H}$ and in the concentration of bicarbonate in the aqueous humour and the blood after the administration of Diamox approached to within 10-20 per cent. of the steady-state values in 1 to 2 hrs. Fig. 1 shows the concentration of total carbon dioxide in the arterial blood of individual rabbits given repeated doses of Diamox. It was found that the concentration of total carbon dioxide in the plasma decreased by approximately $6 \mathrm{mM} / \mathrm{kg}$. $\mathrm{H}_{2} \mathrm{O}$ in 30 to 60 minutes.

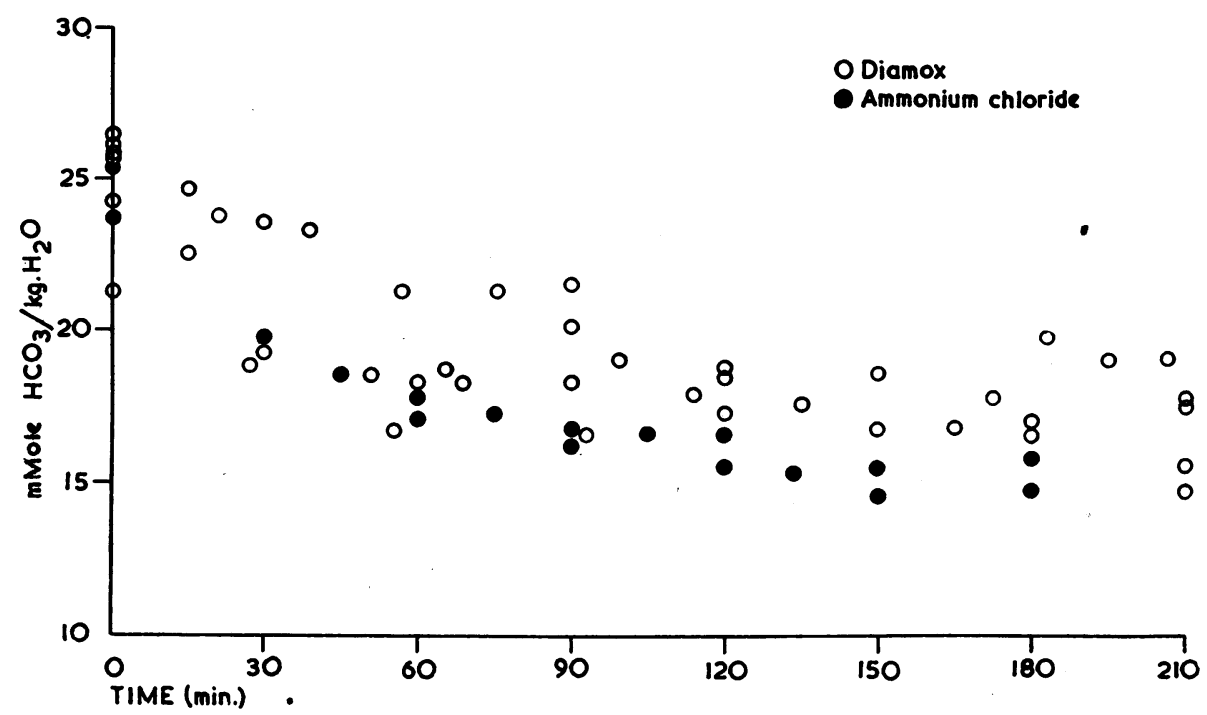

FIG. 1.-Concentration of bicarbonate in arterial plasma of conscious rabbits given Diamox intravenously ( $50 \mathrm{mg}$. $/ \mathrm{kg}$. initially followed by $25 \mathrm{mg} . / \mathrm{kg}$. hrly) and ammonium chloride orally (270 mg./kg.).

The composition of the plasma and aqueous humour of conscious rabbits given an intravenous injection of Diamox 15 minutes previously are recorded in Tables II and III (opposite). The $p \mathrm{H}$ of the blood was significantly below that in the control series but the concentration of bicarbonate remained unchanged. The calculated value of $p \mathrm{CO}_{2}$ in the blood indicated a significant increase. A similar elevation in the $\mathrm{CO}_{2}$ tension and a fall in the $p \mathrm{H}$ of arterial blood in human subjects 30 to 60 minutes after the oral administration of Diamox in doses of $25 \mathrm{mg}$. $/ \mathrm{kg}$. has been reported by Cranston, Sanderson, and Stapleton (1955). Further indications that Diamox can cause a temporary elevation of arterial $\mathrm{CO}_{2}$ tension is to be seen in the experimental results in dogs of Maren, Wadsworth, Yale, and Alonso (1954).

The $p \mathrm{H}$ in the aqueous humour was also lower than in the control series 
TABLE II

EFFECT OF DIAMOX (50 mg./kg. BODY WT.) ON COMPOSITION OF ARTERIAL PLASMA AND AQUEOUS HUMOUR

Samples were removed 15 min. after intravenous injection of Diamox

\begin{tabular}{|c|c|c|c|c|c|c|}
\hline & & & Plasma & Aqueous Humour & Aq-P1 & $\mathrm{Aq} / \mathrm{Pl}$ \\
\hline $\begin{array}{l}p \mathrm{H} \\
\mathrm{H}^{+} \\
\mathrm{Total}^{+} \mathrm{Co}_{2} \\
\mathrm{HCO}^{-}{ }_{3} \\
\mathrm{pCO}_{2}\end{array}$ & $\begin{array}{l}\ldots \\
\cdots \\
\cdots \\
\ldots \\
\ldots\end{array}$ & $\begin{array}{l}\cdots \\
\cdots \\
\cdots \\
\cdots \\
\cdots\end{array}$ & $\begin{array}{c}7 \cdot 34 \pm 0 \cdot 013(12) \\
4 \cdot 57 \times 10^{-8} \\
25 \cdot 3 \pm 0 \cdot 58(12) \\
23 \cdot 9 \pm 0.63(12) \\
44 \pm 1 \cdot 8(12)\end{array}$ & $\begin{array}{c}7 \cdot 45 \pm 0.020(12) \\
3 \cdot 55 \times 10^{-8} \\
26 \cdot 0 \pm 0 \cdot 50(11) \\
24 \cdot 8 \pm 0 \cdot 51(11) \\
38 \pm 1 \cdot 9(11)\end{array}$ & $\begin{array}{c}0.11 \pm 0.02(7) \\
-1.02 \times 10^{-8} \\
0.70 \pm 0.55(7) \\
0.80 \pm 0.47(7) \\
-6 \pm 2.35(7)\end{array}$ & $\begin{array}{l}\overline{0.77} \\
1.03 \\
1.03 \\
0.86\end{array}$ \\
\hline
\end{tabular}

TABLE III

EFFECT OF $20 \mathrm{mg}$. DIAMOX/kg. BODY WT. ON COMPOSITION OF ARTERIAL PLASMA AND AQUEOUS HUMOUR OF CONSCIOUS RABBITS Samples withdrawn 15 minutes after intravenous injection of Diamox

\begin{tabular}{|c|c|c|c|c|c|c|}
\hline & & & Plasma & Aqueous Humour & $\mathbf{A q}-\mathbf{P l}$ & $\mathbf{A q} / \mathbf{P 1}$ \\
\hline $\begin{array}{l}p \mathrm{H} \\
\mathrm{H}^{+} \\
\mathrm{Total}^{+} \mathrm{CO}_{2} \\
\mathrm{HCO}^{-} \\
\mathrm{pCO}_{2}\end{array}$ & $\begin{array}{l}\cdots \\
\cdots \\
\cdots \\
\cdots \\
\cdots\end{array}$ & $\begin{array}{l}\cdots \\
\cdots \\
\cdots \\
\cdots \\
\cdots\end{array}$ & $\begin{array}{l}7 \cdot 33 \pm 0.014(9) \\
4 \cdot 68 \times 10^{-8} \\
26 \cdot 2 \pm 1 \cdot 01(9) \\
24 \cdot 7 \pm 1.02(9) \\
46 \pm 2 \cdot 5\end{array}$ & $\begin{array}{l}7 \cdot 51 \pm 0.025(9) \\
3 \cdot 10 \times 10^{-8} \\
28 \cdot 5 \pm 1 \cdot 60(9) \\
27 \cdot 4 \pm 1 \cdot 57(9) \\
35 \pm 1 \cdot 3\end{array}$ & $\begin{array}{c}0 \cdot 18 \pm 0.023 \\
-1 \cdot 58 \times 10^{-8} \\
2 \cdot 3 \pm 1 \cdot 30 \\
2 \cdot 3 \pm 1 \cdot 77 \\
-11 \pm 3 \cdot 6\end{array}$ & $\begin{array}{l}-\overline{0.66} \\
1.09 \\
1 \cdot 11 \\
0.76\end{array}$ \\
\hline
\end{tabular}

but it remained significantly above that in the blood. The $p \mathrm{CO}_{2}$ was not significantly above that in the control series, but the differences in the values of the aqueous humour and blood of individual rabbits showed a greater scatter than in the control series. In general the $p \mathrm{CO}_{2}$ in the blood was higher than in the aqueous humour. The concentration of bicarbonate, unlike that in the blood, was significantly lower than in the control series and closely approached that in the plasma. Thus, the excess concentration of bicarbonate in the aqueous humour of the two series of rabbits given Diamox dropped nearly to zero within 15 minutes.

The composition of the arterial blood and aqueous humour of conscious rabbits $2.5 \mathrm{hrs}$ after an initial intravenous injection of Diamox are recorded in Tables IV and V (overleaf). Two series of experiments were made using different dosages of Diamox to see whether the effect varied appreciably with the amount of drug given. In the first series an initial injection of $20 \mathrm{mg} . / \mathrm{kg}$. followed by $10 \mathrm{mg} . / \mathrm{kg}$. at hourly intervals was administered, and in the second series the dosage was increased five times. In spite of this difference the response in the two series appeared to be very similar. The dosage of $100 \mathrm{mg} . / \mathrm{kg}$. is at least twenty times that which will induce an appreciable fall in the intra-ocular pressure of rabbits (Gloster and Perkins, 1955b). The $p \mathrm{H}$ of the blood was similar to that measured 15 minutes after giving Diamox, but the concentration of bicarbonate in the plasma showed a significant decrease. The $p \mathrm{CO}_{2}$ was similar to that in normal rabbits and in this respect differed from the elevated values shown in Tables II and III. Thus the increase of the $p \mathrm{CO}_{2}$ was only a transient effect seen in the period immediately after Diamox was given. 
TABLE IV

EFFECT OF DIAMOX GIVEN INTRAVENOUSLY 2.5 HRS PREVIOUSLY TO CONSCIOUS RABBITS

Initial intravenous dose of $20 \mathrm{mg} . / \mathrm{kg}$. body wt. followed by $10 \mathrm{mg} . / \mathrm{kg}$. body wt. 1 and $2 \mathrm{hrs}$ later

\begin{tabular}{|c|c|c|c|c|c|}
\hline & & Plasma & Aqueous Humour & Aq-PI & $\mathrm{Aq} / \mathrm{Pl}$ \\
\hline $\begin{array}{ll}p \mathrm{H} & \ldots \\
\mathrm{H}^{+} & . . \\
\mathrm{Total}^{\mathrm{C}} \mathrm{CO}_{2} & . . \\
\mathrm{HCO}^{-} & . . \\
\mathrm{pCO}_{2} & . .\end{array}$ & $\begin{array}{l}\cdots \\
\cdots \\
\cdots \\
\cdots \\
\cdots\end{array}$ & $\begin{array}{l}7 \cdot 34 \pm 0 \cdot 022(8) \\
4 \cdot 57 \times 10^{-8} \\
19 \cdot 2 \pm 0 \cdot 88(8) \\
18 \cdot 2 \pm 0 \cdot 87(8) \\
34 \pm 1 \cdot 3\end{array}$ & $\begin{array}{l}7 \cdot 44 \pm 0 \cdot 018(8) \\
3 \cdot 63 \times 10^{-8} \\
25 \cdot 3 \pm 0 \cdot 95(8) \\
24 \cdot 2 \pm 0 \cdot 92(8) \\
35 \pm 1 \cdot 7\end{array}$ & $\begin{array}{c}0 \cdot 10 \pm 0 \cdot 03 \\
-2 \cdot 31 \times 10^{-8} \\
6 \cdot 1 \pm 0 \cdot 30 \\
6 \cdot 0 \pm 0 \cdot 26 \\
1 \pm 2 \cdot 1\end{array}$ & $\begin{array}{l}0.79 \\
1.32 \\
1.33 \\
1.03\end{array}$ \\
\hline
\end{tabular}

TABLE V

EFFECT OF DIAMOX ON COMPOSITION OF ARTERIAL PLASMA AND AQUEOUS HUMOUR

Diamox $100 \mathrm{mg}$. $/ \mathrm{kg}$. given intravenously followed by $50 \mathrm{mg} . / \mathrm{kg}$. after 60 and 120 minutes. Samples removed at $2.5 \mathrm{hrs}$

\begin{tabular}{|c|c|c|c|c|c|c|}
\hline & & & Arterial Plasma & Aqueous Humour & Aq-Pl & $\mathbf{A q} / \mathbf{P I}$ \\
\hline $\begin{array}{l}p \mathrm{H} \\
\mathrm{H}^{+} \ldots \\
\mathrm{Total}^{+} \mathrm{CO}_{2} \\
\mathrm{HCO}^{-}{ }_{3} \\
\mathrm{pCO}_{2}\end{array}$ & $\begin{array}{l}\cdots \\
\cdots \\
\cdots \\
\cdots \\
\cdots\end{array}$ & $\begin{array}{l}\cdots \\
\cdots \\
\cdots \\
\cdots \\
\cdots\end{array}$ & $\begin{array}{l}7 \cdot 36 \pm 0.01(12) \\
4 \cdot 36 \times 10^{-8} \\
17 \cdot 6 \pm 0 \cdot 50(12) \\
16 \cdot 7 \pm 0 \cdot 50(12) \\
29 \pm 1 \cdot 1(12)\end{array}$ & $\begin{array}{c}7 \cdot 50 \pm 0 \cdot 02(11) \\
3 \cdot 16 \times 10^{-8} \\
23 \cdot 1 \pm 0 \cdot 30(10) \\
22 \cdot 2 \pm 0 \cdot 30(10) \\
29 \pm 1 \cdot 2(10)\end{array}$ & $\begin{array}{l}0.13 \pm 0.03 \\
-1.20 \times 10^{-8} \\
5.4 \pm 0.46 \\
5.5 \pm 0.38 \\
0 \pm 1.9\end{array}$ & $\begin{array}{l}\overline{0 \cdot 72} \\
1 \cdot 31 \\
1 \cdot 33 \\
1 \cdot 0\end{array}$ \\
\hline
\end{tabular}

The $p \mathrm{H}$ of the aqueous humour was similar to that observed 15 minutes after the administration of Diamox, and again exceeded that in the plasma. The concentration of bicarbonate in the aqueous humour also showed no change compared with the value after 15 minutes. However, owing to the decrease in the concentration of bicarbonate in the plasma, there was an excess concentration of bicarbonate in the aqueous humour similar to that in untreated animals.

The concentrations of total carbon dioxide in the aqueous humour and plasma after the administration of Diamox have been reported by Green, Bocher, and Leopold (1955) and by Becker (1955b). Unfortunately these authors' results do not agree with the present results. Green and others (1955) reported that Diamox caused no change in the concentrations of total $\mathrm{CO}_{2}$ in the aqueous humour or plasma of rabbits. No measurements of $p \mathrm{H}$ were taken, but it is evident from their results that many of their animals were in varying stages of acidosis before the start of the experiments, for over half of the animals injected with Diamox had an initial concentration of total $\mathrm{CO}_{2}$ in the plasma of less than $20 \mathrm{mM} / 1$. This contrasts with the values of $24.2 \pm 1.05$ (12) $\mathrm{mM} / \mathrm{kg} . \mathrm{H}_{2} \mathrm{O}$ in the plasma of normal rabbits having a $p \mathrm{H}$ of $7.43 \pm 0.012$ (12). Their method of analysis is also open to criticism (Grant, 1956). In an agreement with the present observation, Becker (1955b) found that Diamox decreased the concentration of bicarbonate in the aqueous humour. However, Becker also reported that Diamox 
had no significant effect on the concentration of bicarbonate in the plasma. This is difficult to understand, in that it is widely recognized that Diamox, even in a very low dosage, will cause an excretion of bicarbonate into the urine and a consequent decrease in the concentration of bicarbonate in the blood. The explanation may, however, lie in the method of analysis. The samples of plasma analysed by Becker were taken from the heart and would therefore comprise a variable mixture of arterial and venous blood. In comparison, the present analyses were made immediately on samples of arterial whole blood freshly drawn from the heat-dilated median artery of the ear.

Effect of Diamox on the Composition of the Blood and the Aqueous Humour of Rabbits in which Kidney Function has been Eliminated.-In the first series of rabbits, the blood and aqueous humour of untreated animals were analysed 3 hours after the operation; in the second series $50 \mathrm{mg}$. Diamox $/ \mathrm{kg}$. was injected intravenously 30 minutes after the operation and samples of aqueous humour and arterial blood were taken 2.5 hours later. The results in the untreated animals are recorded in Table VI. The $p \mathrm{H}$ and the concentration of bicarbonate in the blood and aqueous humour were significantly below those in normal animals. The concentration of bicarbonate in the aqueous humour of individual rabbits was, however, significantly above that in the blood and similar in value to that in normal rabbits.

TABLE VI

COMPOSITION OF ARTERIAL PLASMA AND AQUEOUS HUMOUR OF ANIMALS 3 HRS AFTER LIGATION OF RENAL ARTERIES

\begin{tabular}{|c|c|c|c|c|c|}
\hline & & Plasma & Aqueous Humour & $\mathrm{Aq}-\mathrm{Pl}$ & $\mathbf{A q} / \mathbf{P l}$ \\
\hline 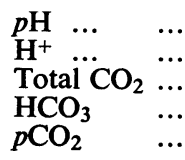 & $\begin{array}{l}\cdots \\
\cdots \\
\cdots \\
\cdots \\
\cdots\end{array}$ & $\begin{array}{c}7 \cdot 29 \pm 0.02(5) \\
5.13 \times 10^{-8} \\
20.0 \pm 1 \cdot 15(5) \\
18 \cdot 8 \pm 1.06(5) \\
38 \pm 3.5\end{array}$ & $\begin{array}{l}7 \cdot 39 \pm 0 \cdot 02(5) \\
4 \cdot 26 \times 10^{-8} \\
26 \cdot 6 \pm 0 \cdot 35(5) \\
25 \cdot 2 \pm 0 \cdot 35(5) \\
44 \pm 0 \cdot 7\end{array}$ & $\begin{array}{c}0 \cdot 10 \pm 0 \cdot 02 \\
-1 \cdot 13 \times 10^{-8} \\
6 \cdot 6 \pm 1 \cdot 25 \\
6 \cdot 4 \pm 1 \cdot 18 \\
6 \pm 3 \cdot 4\end{array}$ & $\begin{array}{l}0 \cdot 83 \\
1 \cdot 33 \\
1 \cdot 34 \\
1 \cdot 16\end{array}$ \\
\hline
\end{tabular}

The effect of Diamox on the operated rabbits is recorded in Table VII. The $p \mathrm{H}$ of the blood and aqueous humour dropped below the mean values recorded in the untreated series, and calculation of the $\mathrm{CO}_{2}$ tension showed this to increase to high values compared with the tensions in untreated

TABLE VII

EFFECT OF DIAMOX (50 mg./kg.) ON COMPOSITION OF ARTERIAL PLASMA AND AQUEOUS HUMOUR OF RABBITS 3 HRS AFTER LIGATION OF RENAL ARTERIES

Diamox given intravenously $30 \mathrm{~min}$. after ligation of renal arteries

\begin{tabular}{|c|c|c|c|c|c|c|}
\hline $\begin{array}{l}p \mathrm{H} \\
\mathrm{H}^{+} \ldots \\
\mathrm{Total}_{\mathrm{CO}} \mathrm{CO}_{2} \\
\mathrm{HCO}_{3} \\
\mathrm{pCO}_{2}\end{array}$ & $\begin{array}{l}\cdots \\
\cdots \\
\cdots \\
\cdots \\
\cdots\end{array}$ & $\begin{array}{l}\cdots \\
\cdots \\
\cdots \\
\cdots \\
\cdots\end{array}$ & $\begin{array}{l}7 \cdot 10 \pm 0 \cdot 05(5) \\
7 \cdot 94 \pm 10^{-8} \\
25 \cdot 1 \pm 1 \cdot 9(5) \\
22 \cdot 8 \pm 1 \cdot 8(5) \\
73 \pm 4 \cdot 1\end{array}$ & $\begin{array}{l}7 \cdot 25 \pm 0 \cdot 03(4) \\
5 \cdot 62 \times 10^{-8} \\
29 \cdot 4 \pm 2 \cdot 0(4) \\
27 \cdot 4 \pm 2 \cdot 0(4) \\
64 \pm 1 \cdot 5\end{array}$ & $\begin{array}{l}0 \cdot 17 \pm 0 \cdot 06 \\
-2 \cdot 32 \times 10^{-8} \\
5 \cdot 2 \pm 1 \cdot 0 \\
6 \cdot 0 \pm 0 \cdot 83 \\
-7 \pm 5.9\end{array}$ & $\begin{array}{l}\overline{0 \cdot 71} \\
1 \cdot 22 \\
1 \cdot 28 \\
0 \cdot 88\end{array}$ \\
\hline
\end{tabular}


rabbits. The concentrations of bicarbonate in the blood and aqueous humour were higher than in the untreated animals. In individual animals, the concentration of bicarbonate in the aqueous humour again exceeded that in the arterial plasma by an amount similar to that seen in the control and the normal series of rabbits.

The condition of acidosis observed in these animals is at variance with the observations of Becker (1955b). He reported that the concentrations of total carbon dioxide in the plasma and the aqueous humour of rabbits nephrectomized under pentabarbital anaesthesia 18 to 24 hours previously did not differ from those in unoperated animals. In the present study the decision to use animals 3 rather than 24 hours after the operation was prompted by the desire to keep pathological changes to a minimum. Thus at 24 hours the blood pressure and the intra-ocular pressure are below normal and the blood-aqueous barrier abnormally permeable to fluorescein. In view of Becker's observations, however, samples of the aqueous humour and blood of animals nephrectomized 24 hours previously were also made. The results did not differ significantly from those recorded in Tables VI and VII. In three control rabbits the mean concentrations of total carbon dioxide in the plasma and in the aqueous humour were 17.5 and $24.5 \mathrm{mM} / \mathrm{kg}$. $\mathrm{H}_{2} \mathrm{O}$ respectively, and in the animals given Diamox $(50 \mathrm{mg} . / \mathrm{kg} .2 .5 \mathrm{hrs}$ previously) the corresponding values were 16.5 and $21.0 \mathrm{mM} / \mathrm{kg}$. $\mathrm{H}_{2} \mathrm{O}$.

Chemical analysis of the blood and aqueous humour of rabbits after the administration of ammonium chloride was made in order to help interpret the observations of Becker (1955a) that Diamox lowers the intra-ocular pressure of animals pre-treated with high doses of ammonium chloride by mouth. A similar amount of ammonium chloride $(270 \mathrm{mg} . / \mathrm{kg}$.) to that used by Becker and recommended by Maren and Wadsworth (1954) to block the renal effect of Diamox, was given to conscious rabbits. Repeated analysis of the concentration of total $\mathrm{CO}_{2}$ in the blood showed a fall in concentration to approximately $16 \mathrm{mM} / \mathrm{kg} \cdot \mathrm{H}_{2} \mathrm{O}$ within 60 minutes and little further change in the following 2 hours.

The composition of the plasma and aqueous humour of conscious rabbits 2.5 hours after the oral administration of $270 \mathrm{mg}$. $\mathrm{NH}_{4} \mathrm{Cl} / \mathrm{kg}$. are recorded in Table VIII. The concentration of bicarbonate in the aqueous humour of individual animals exceeded that in the arterial plasma, but the excess

TABLE VIII

ANIMALS GIVEN $270 \mathrm{mg}$. AMMONIUM CHLORIDE/kg. BY STOMACH TUBE 2.5 HRS EARLIER

\begin{tabular}{|c|c|c|c|c|c|c|}
\hline & & & Plasma & Aqueous Humour & $A q-P l$ & $\mathbf{A q} / \mathbf{P l}$ \\
\hline $\begin{array}{l}p \mathrm{H} \\
\mathrm{H} \\
\mathrm{H} \\
\mathrm{Total}^{+} \\
\mathrm{CCO}_{2} \\
\mathrm{HCO}_{3} \\
\mathrm{CCO}_{2}\end{array}$ & $\begin{array}{l}\ldots \\
\ldots \\
\ldots \\
\ldots \\
\ldots\end{array}$ & $\begin{array}{l}\ldots \\
\ldots \\
\cdots \\
\cdots \\
\ldots\end{array}$ & $\begin{array}{l}7 \cdot 14 \pm 0 \cdot 02(12) \\
7 \cdot 25 \times 10^{-8} \\
18 \cdot 7 \pm 0 \cdot 84(12) \\
17 \cdot 1 \pm 0 \cdot 76(12) \\
51 \pm 1 \cdot 9\end{array}$ & $\begin{array}{l}7 \cdot 29 \pm 0 \cdot 02(12) \\
5 \cdot 12 \times 10^{-8} \\
21 \cdot 5 \pm 0 \cdot 82(12) \\
20 \cdot 1 \pm 1 \cdot 83(12) \\
44 \pm 2 \cdot 8\end{array}$ & $\begin{array}{l}0 \cdot 15 \pm 0.29 \\
-2 \cdot 13 \times 10^{-8} \\
2 \cdot 8 \pm 0.90 \\
3 \cdot 0 \pm 0 \cdot 86 \\
-7 \pm 2 \cdot 9\end{array}$ & $\begin{array}{l}0.70 \\
1 \cdot 15 \\
1 \cdot 18 \\
0.86\end{array}$ \\
\hline
\end{tabular}


was considerably less than in untreated animals. The $p \mathrm{H}$ and the concentrations of bicarbonate in the plasma and the aqueous humour were well below those in untreated animals, and the calculated value for the $\mathrm{CO}_{2}$ tension exceeded that in normal animals. The increased acidity was probably caused mainly by the acid nature of ammonium chloride and differs in this respect from the more prolonged action of ammonium chloride in producing a hyperchloraemia and a fully compensated type of metabolic acidosis (Haldane, 1921; Haldane, Linder, Hilton, and Fraser, 1928).

The composition of the plasma and aqueous humour of animals given ammonium chloride $270 \mathrm{mg}$. $/ \mathrm{kg}$. by mouth followed by Diamox intravenously is recorded in Table IX. The concentration of bicarbonate in the aqueous humour exceeded that in the arterial plasma by an amount similar to that seen in the previous series of experiments; the $p \mathrm{H}$ of the blood and aqueous humour appeared to be slightly higher than in the previous series, and the bicarbonate concentrations were essentially unchanged. The calculated value for the $\mathrm{CO}_{2}$ tension in the blood and aqueous humour showed them to be similar to those in normal rabbits.

TABLE IX

ANIMALS GIVEN $270 \mathrm{mg}$. AMMONIUM CHLORIDE/kg., $50 \mathrm{mg}$. DIAMOX/kg. BEING INJECTED INTRAVENOUSLY AFTER $1.5 \mathrm{HRS}$ AND A FURTHER $25 \mathrm{mg}$./kg. AFTER $1 \mathrm{HR}$

Samples removed $3.5 \mathrm{hrs}$ after administration of ammonium chloride

\begin{tabular}{|c|c|c|c|c|c|}
\hline & & Plasma & Aqueous Humour & $\mathrm{Aq}-\mathrm{Pl}$ & $\mathbf{A q} / \mathbf{P l}$ \\
\hline $\begin{array}{ll}p \mathrm{H} & \ldots \\
\mathrm{H}^{+} & \ldots \\
\mathrm{Total}^{\mathrm{C}} \mathrm{CO}_{2} & \ldots \\
\mathrm{HCO}_{3} & \ldots \\
\mathrm{pCO}_{2} & \ldots\end{array}$ & $\begin{array}{l}\cdots \\
\cdots \\
\cdots \\
\cdots \\
\cdots\end{array}$ & $\begin{array}{l}7 \cdot 22 \pm 0 \cdot 015(12) \\
6 \cdot 04 \times 10^{-8} \\
17 \cdot 5 \pm 0 \cdot 85(12) \\
16 \cdot 3 \pm 0 \cdot 81(12) \\
38 \pm 1 \cdot 6\end{array}$ & $\begin{array}{l}7 \cdot 40 \pm 0.072(12) \\
3.98 \times 10^{-8} \\
20 \cdot 3 \pm 0.84(12) \\
19 \cdot 3 \pm 0.82(12) \\
32 \pm 0 \cdot 9\end{array}$ & $\begin{array}{c}0.18 \pm 0.02 \\
-2.06 \times 10^{-8} \\
2.8 \pm 0.93 \\
3.0 \pm 0.92 \\
-6 \pm 3.4\end{array}$ & $\begin{array}{l}\overline{0} \\
0 \cdot 66 \\
1 \cdot 16 \\
1 \cdot 18 \\
0 \cdot 84\end{array}$ \\
\hline
\end{tabular}

Effect of Diamox on the Concentration of Sodium in the Blood and Aqueous Humour.- In view of the observations that Diamox caused a decrease in the concentration of bicarbonate in the aqueous humour of approximately $6 \mathrm{mEq} / \mathrm{kg}$. $\mathrm{H}_{2} \mathrm{O}$, studies were made to see if a corresponding decrease occurred in the concentration of the main cation, sodium. In ten control rabbits the mean concentration of sodium in the first eye was $135.6 \pm 0.99$ $\mathrm{mEq} / \mathrm{kg}$. $\mathrm{H}_{2} \mathrm{O}$, and in the second eye, removed $15 \mathrm{~min}$. later, it was $135.9 \pm 1.02 \mathrm{mEq} / \mathrm{kg} . \mathrm{H}_{2} \mathrm{O}$. In the same series the mean difference in the concentration of sodium between the second and first eyes of individual rabbits was $1 \cdot 0 \pm 0 \cdot 21 \mathrm{mEq} / \mathrm{kg}$. $\mathrm{H}_{2} \mathrm{O}$.

The effect of Diamox on the concentration of sodium in the aqueous humour and arterial plasma of four conscious rabbits given Diamox is recorded in Table X (overleaf). In two animals the concentration of sodium in the plasma and aqueous humour showed an increase, while in the other two the changes were not significant. 
TABLE X

CONCENTRATION OF SODIUM IN PLASMA AND AQUEOUS HUMOUR OF CONSCIOUS RABBITS BEFORE ( $\mathrm{Pl}_{1}$ AND Aq $)$ AND 20 MINUTES AFTER ( $\mathrm{Pl}_{2}$ AND Aq $\left.\mathrm{Aq}_{2}\right)$ INTRAVENOUS INJECTION OF DIAMOX $(50 \mathrm{mg} . / \mathrm{kg}$.

Results expressed as mEq/kg. $\mathrm{H}_{2} \mathrm{O}$

\begin{tabular}{c|c|c|c|c|c}
\hline $\mathrm{Pl}_{1}$ & $\mathrm{Pl}_{2}$ & $\mathrm{Aq}_{1}$ & $\mathrm{Aq}_{2}$ & $\mathrm{Aq}_{1} / \mathrm{Pl}_{\mathbf{1}}$ & $\mathrm{Aq}_{2} / \mathrm{Pl}_{2}$ \\
\hline 151 & 155 & 136 & 139 & 0.89 & 0.90 \\
144 & 145 & 137 & 136 & 0.95 & 0.94 \\
149 & 151 & 136 & 134 & 0.91 & 0.89 \\
151 & 156 & 139 & 144 & 0.92 & 0.92 \\
\hline
\end{tabular}

In separate experiments the concentrations of sodium in the blood and aqueous humour of untreated rabbits were compared with analyses made on conscious rabbits given Diamox $(50 \mathrm{mg} . / \mathrm{kg}$.) intravenously 2.5 hours previously. The results, summarized in Table XI, showed that there was no significant change in the concentration of sodium in the plasma or aqueous humour.

TABLE XI

EFFECT OF DIAMOX ON CONCENTRATION OF SODIUM IN ARTERIAL PLASMA AND AQUEOUS HUMOUR OF CONSCIOUS RABBITS

Series A represents a control group of rabbits.

Animals in Series B were given $50 \mathrm{mg}$. Diamox $/ \mathrm{kg}$. intravenously and a further $25 \mathrm{mg} . / \mathrm{kg} .1$ and 2 hrs later.

Samples withdrawn $2.5 \mathrm{hrs}$ after initial injection

\begin{tabular}{c|c|c|c|c}
\hline Series & Plasma & Right Aqueous & Left Aqueous & Aq/Pl \\
\cline { 1 - 2 } A & $143.6 \pm 1 \cdot 64(10)$ & $135 \cdot 6 \pm 0.99(10)$ & $135 \cdot 9 \pm 1.02(10)$ & $0.945 \pm 0.01(10)$ \\
B & $144.9 \pm 1 \cdot 30(10)$ & $136.1 \pm 1 \cdot 18(10)$ & $136.8 \pm 1.33(10)$ & $0.945 \pm 0.01(10)$ \\
\hline
\end{tabular}

Effect of Diamox and Ammonium Chloride on the Transfer of Ascorbic Acid across the Blood-Aqueous Barrier.-In view of the observation that in certain respects ammonium chloride affects the formation and composition of the aqueous humour in a similar way to Diamox, it was considered of value to compare its action with that of Diamox on the accumulation in the aqueous humour of a compound known to be actively transported across the blood-aqueous barrier, namely, ascorbic acid. These results have been reported in a preliminary communication to the Physiological Society (Langham and Lee, 1955c).

In rabbits, guinea-pigs, and humans, it has been shown that a rise in the concentration of ascorbic acid in the plasma leads to an increase in the concentration in the aqueous humour, even though the raised plasma level may be considerably below that of the aqueous humour (Kinsey, 1947; Langham, 1950; Linnér, 1952; Bárány and Langham, 1955). In rabbits the secretion of ascorbic acid into the aqueous humour reaches a maximum at a plasma concentration of $2-3 \mathrm{mg}$. $/ 100 \mathrm{ml}$. and gives a mean concentra- 
tion of $67 \cdot 5 \pm 2 \cdot 1 \mathrm{mg} . / 100 \mathrm{ml}$. in the aqueous humour (Bárány and Langham, 1955).

The effect of Diamox and ammonium chloride on the secretion of ascorbic acid into the aqueous humour of conscious rabbits is recorded in Table XII. The concentration of ascorbic acid in the plasma of these animals was kept at a mean value of $5-10 \mathrm{mg} . / 100 \mathrm{ml}$., which well exceeds the level of $2-3 \mathrm{mg}$./ $100 \mathrm{ml}$. required to ensure a maximal rate of transfer in normal rabbits. This was done to exclude a possible vasomotor action of Diamox in influencing the rate of secretion of ascorbic acid; thus the rate of transfer of ascorbic acid may be varied by a change in uveal blood flow (Linnér, 1952; Langham, 1955b). The aqueous humour from one eye was removed 3 hours after the initial injection of ascorbic acid. At this time the concentration of ascorbic acid in the aqueous humour had approached the maximum steady-state value of approximately $70 \mathrm{mg} . / 100 \mathrm{ml}$. (Table XII). Then Diamox or ammonium chloride was given to the two experimental series of animals, and the aqueous humour in the second eye was removed 3 hours later. The results showed that the secretion of ascorbic acid had been maintained in these conditions. The analyses of Becker (1956) of the concentration of ascorbic acid in the aqueous humour of nephrectomized rabbits after giving Diamox are similar to those recorded here.

TABLE XII

EFFECT OF DIAMOX ( $50 \mathrm{mg} . / \mathrm{kg}$. FOLLOWED BY $25 \mathrm{mg} . / \mathrm{kg}$. AT HOURLY INTERVALS) AND AMMONIUM CHLORIDE $(270 \mathrm{mg} . / \mathrm{kg}$.) ON CONCENTRATION OF ASCORBIC ACID (mg./100 ml.) IN AQUEOUS HUMOUR OF CONSCIOUS RABBITS

Ammonium chloride (orally) and Diamox (intravenously) were given after removal of $\mathrm{Aq}_{1}$. All animals were given an initial intravenous injection of a solution of sodium ascorbate $(p \mathrm{H} 7 \cdot 0)$, followed by intramuscular injections hourly to maintain the concentration of ascorbic acid in the plasma at 5-10 mg. $/ 100 \mathrm{ml}$.

\begin{tabular}{|c|c|c|c|c|c|}
\hline \multicolumn{3}{|c|}{ Series } & $\mathrm{Aq}_{1}(3 \mathrm{hrs})$ & $\mathrm{Aq}_{2}(6 \mathrm{hrs})$ & $\mathbf{A q} q_{2}-\mathbf{A q} q_{1}$ \\
\hline $\begin{array}{l}\text { Controls ... } \\
\mathrm{NH}_{4} \mathrm{Cl} \\
\text { Diamox }\end{array}$ & $\begin{array}{l}\cdots \\
\cdots \\
\cdots\end{array}$ & $\begin{array}{l}\cdots \\
\cdots \\
\cdots\end{array}$ & $\begin{array}{l}62 \cdot 5 \pm 2 \cdot 6(8) \\
61 \cdot 3 \pm 2 \cdot 4(8) \\
65 \cdot 3 \pm 1 \cdot 6(8)\end{array}$ & $\begin{array}{l}69 \cdot 9 \pm 3 \cdot 2(8) \\
76 \cdot 0 \pm 2 \cdot 6(8) \\
83 \cdot 3 \pm 2 \cdot 1(8)\end{array}$ & $\begin{array}{r}7 \cdot 4 \pm 0.9 \\
13 \cdot 7 \pm 1 \cdot 5 \\
18 \cdot 0 \pm 2 \cdot 1\end{array}$ \\
\hline
\end{tabular}

Effect of Diamox and Ammonium Chloride on Transfer of Fluorescein from the Bloodstream into the Anterior Chamber.-The concentrations of fluorescein in three areas of the anterior chamber after an intravenous injection of a solution of sodium fluorescein are shown in Fig. 2 (overleaf). It took about 4 minutes for fluorescein to pass in a significant amount into the anterior chamber but then the concentration in front of the lens started to increase rapidly. The concentrations of fluorescein in the central and corneal areas of the anterior chamber lagged behind that in the lens area for approximately 30 minutes. In the period of approximately 4 minutes before the dye was recorded in a significant concentration in the anterior chamber, the aqueous humour, illuminated by the focal vertical beam of light from the slit lamp, changed from black to a faint greyish and then just perceptibly 
green colour. This was, however, too little to record on the fluorophotometer and was probably due to the occasional streamline of fluorescein which passes through the pupil (see Friedenwald and Becker, 1955).

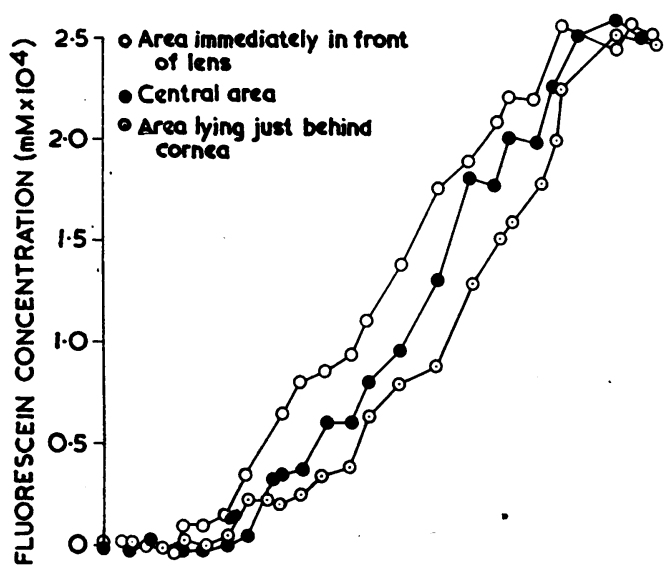

Fig. 2.-Concentration of fluorescein in three areas of aqueous humour after intravenous injection of $1.0 \mathrm{ml}$. of a 10 per cent. solution of sodium fluorescein to an anaesthetized rabbit.

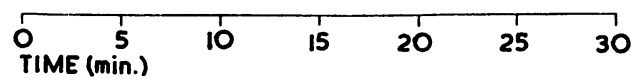

In a series of ten anaesthetized rabbits the mean time taken for fluorescein to appear in the area of the anterior chamber immediately in front of the lens was $248 \pm 26$ seconds. This value, which is based on the curve of accumulation, exceeds those reported by Linnér and Friedenwald (1954) and Kornblueth and Linnér (1955), who recorded the times at which a green colour was first perceptible at the pupillary margin.

The ability of Diamox to modify the appearance time of fluorescein was studied in rabbits $15,60,180$, and 360 minutes after an intravenous injection. The results are recorded in Table XIII. At 15 and 60 minutes after the administration of Diamox, the appearance times were significantly above the mean value of the control series, but at 180 and 360 minutes the values did not exceed the controls, even though Diamox had been administered at hourly intervals.

TABLE XIII

TIME TAKEN FOR FLUORESCEIN TO PASS FROM THE BLOODSTREAM INTO THE AREA OF THE ANTERIOR CHAMBER IMMEDIATELY IN FRONT OF THE LENS

Diamox given intravenously in the stated dosage and repeated hourly at half this dosage

\begin{tabular}{|c|c|c|c|}
\hline & Series & Time (min.) after Diamox & Appearance Times (sec.) \\
\hline \multicolumn{2}{|l|}{ Controls } & - & $248 \pm 26(10)$ \\
\hline $\begin{array}{l}\text { Diamox } \\
\text { (mg./kg.) }\end{array}$ & $\begin{array}{l}50 \\
20 \\
50 \\
50 \\
50\end{array}$ & $\begin{array}{r}15 \\
15 \\
60 \\
180 \\
360\end{array}$ & $\begin{array}{l}328 \pm 24 \cdot 5(6) \\
334 \pm 32(5) \\
348 \pm 21(9) \\
208 \pm 15(9) \\
187 \pm 30(6)\end{array}$ \\
\hline
\end{tabular}


A typical result of an animal given Diamox 1 hour previously is seen in Fig. 3. This shows the increased appearance time and also that the time taken for fluorescein to become evenly distributed in the anterior chamber exceeded that in a control experiment (Fig. 2). This latter observation was emphasized by the unequal distribution of fluorescein after 30 minutes in all animals given Diamox compared with the equal distribution of fluorescein observed in the majority of untreated animals (Langham and Lee, 1955a).

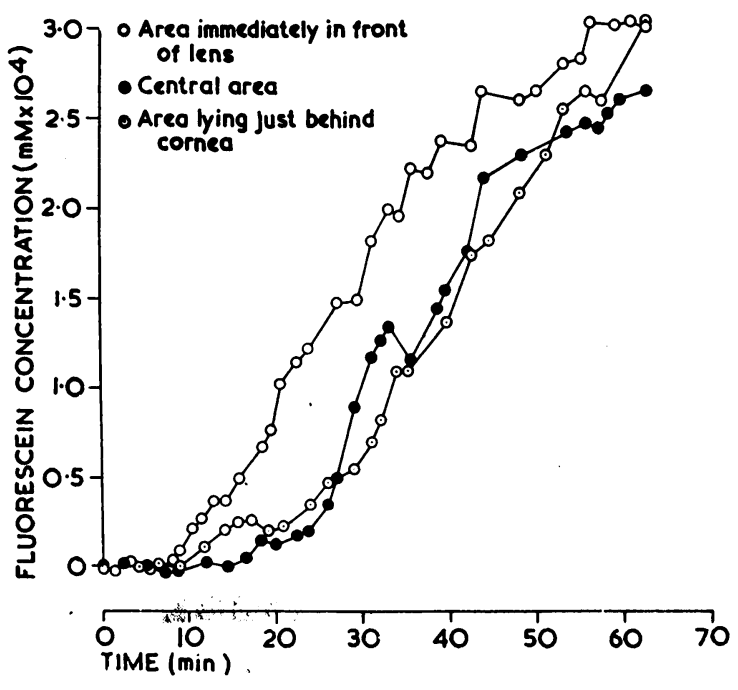

Fig. 3.-Concentration of fluorescein in aqueous humour in a rabbit given $50 \mathrm{mg}$. Diamox $/ \mathrm{kg}$. body wt $1 \mathrm{hr}$ previously. $1.0 \mathrm{ml}$. of a 10 per cent. solution of sodium fluorescein was injected intravenously.

The dosage of Diamox given to the animals well exceeded that needed to reduce the intra-ocular pressure and it is considered that the observed effects on the appearance times reflect its maximum response. It was, however, considered of interest to test whether a low dosage would influence the appearance time since Gloster and Perkins (1955b) observed a lowering of the intra-ocular pressure in animals receiving $5 \mathrm{mg}$. Diamox/ $\mathrm{kg}$. body weight; this is also a similar dosage to that given to patients with glaucoma. In five rabbits given $5 \mathrm{mg}$. Diamox $/ \mathrm{kg}$. body weight 15 minutes previously, the mean appearance time was $300 \pm 25$ seconds, which significantly exceeds the value in untreated animals and is similar to that given greater amounts of the drug.

The effect of Diamox on rabbits in which the renal arteries had been tied was found more difficult to assess owing to an increased permeability of the iris vessels to fluorescein and protein in some animals. Control animals were given fluorescein 2 hours after tying the renal arteries and the mean appearance time was $218 \pm 40$ (5) seconds, which is similar to that found in normal animals. In similar experiments, Diamox $(50 \mathrm{mg} . / \mathrm{kg}$.) was given 1 hour after the operation and fluorescein 1 hour later. The appearance time in these conditions was $280 \pm 31$ (7) seconds. Although this value 
exceeds that in the control series, it cannot be considered statistically different in view of the large standard error.

In a final series of experiments, the fluorescein appearance time of rabbits given ammonium chloride by mouth 1 hour previously was determined. The mean value was $335 \pm 30$ seconds and is significantly higher than the appearance time in untreated animals.

The observation that the rate of formation of the aqueous humour is decreased 1 hour after administration of Diamox agrees with the observations of Becker and Constant (1955). Using the electric tonographic method of Grant (1950) on conscious rabbits, these authors reported that the rate of formation of the aqueous humour was decreased by approximately 63 per cent. 45-60 minutes after intravenous injections of Diamox (100 mg. $/ \mathrm{kg}$.).

Intra-Ocular Pressure Studies. - In a preliminary series of experiments, the observations of Gloster (1955) that Diamox given intravenously to rabbits reduces the intra-ocular pressure within a few minutes were fully confirmed. A typical result in which the intra-ocular and blood pressures were measured are shown in Fig. 4.

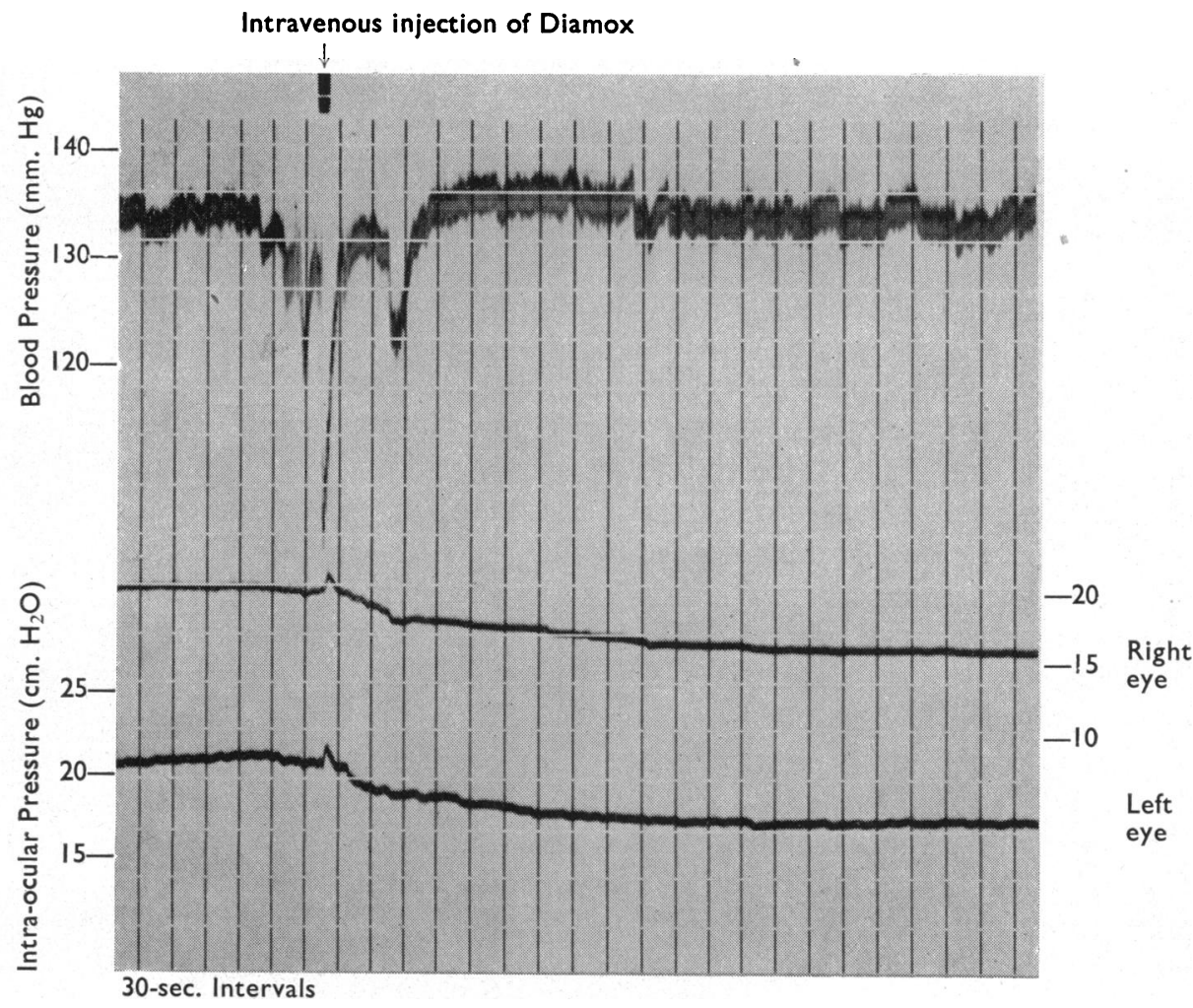

FIG. 4. -Effect of Diamox ( $25 \mathrm{mg}$./kg. body wt) given intravenously on intraocular pressure of a rabbit. 
In similar experiments, Diamox was administered intravenously 2.5 hours after the administration of ammonium chloride, and again Diamox was found to reduce the intra-ocular pressure in all six animals studied. Fig. 5 records a typical result and shows that the fall in the intra-ocular pressure followed a pattern similar to that seen on animals not pre-treated with ammonium chloride. These observations confirm the findings of Becker (1955a), who measured the intra-ocular pressure of rabbits by a tonometric technique after the administration of ammonium chloride.

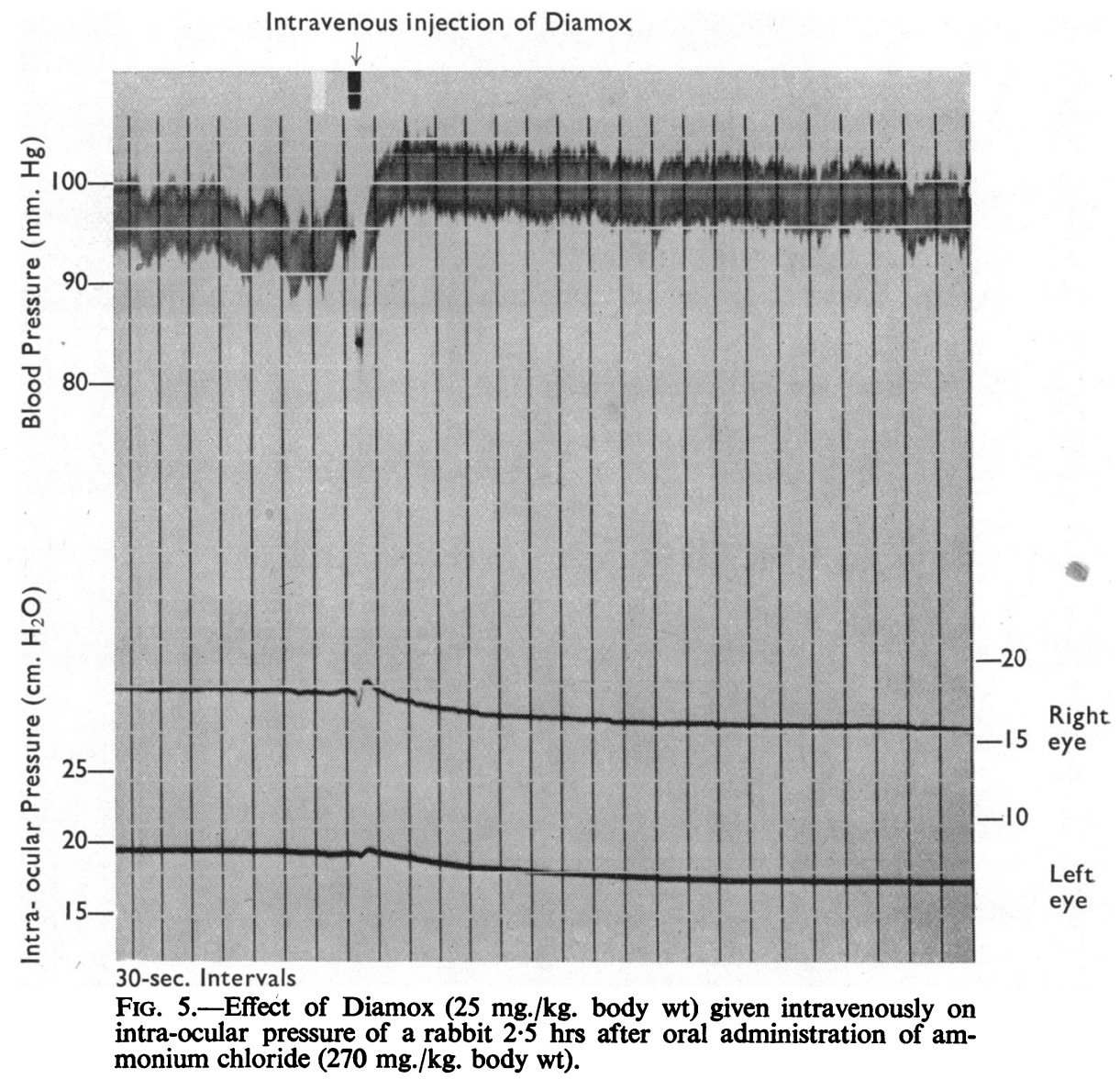

The conventional Schiötz $\mathrm{X}$ tonometer was used to observe the influence of Diamox and ammonium chloride on the intra-ocular pressure over a period of several hours. The manometric technique could not be employed for, although it is more accurate than tonometry, it is unsuitable for recording slow changes in pressure in the eye. In a control series of experiments on anaesthetized rabbits, the intra-ocular pressure was found to fall slowly during a period of $5 \mathrm{hrs}$, and it was found increasingly difficult to obtain reproducible tonometric readings. Attempts were therefore made to record 
tonometric readings on conscious rabbits. In these conditions it was found that the tonometric readings remained essentially unchanged in the two eyes during a period of 5 hours provided the application of local anaesthetic to the eye was kept to a minimum. To achieve an adequate anaesthesia of the corneal epithelium surface one drop of a 1 per cent. solution of pantocaine was instilled into the conjunctival sac and the excess was washed away with an isotonic saline solution 1 minute later. If, however, the local anaesthetic remained on the eye and readings were taken at intervals of 30 minutes there was a tendency for the intra-ocular pressure to fall and remain low. Consequently, the number of readings in these experiments was kept to a minimum.

Fig. 6 shows the relative changes in the intra-ocular pressure of conscious rabbits given Diamox. The pressure fell rapidly and averaged 2 to 3 divisions on the Schiötz scale within 30 to 60 minutes of the intravenous injection. Later, however, there was a significant recovery of the intraocular pressure towards its initial value in spite of further hourly injections of Diamox.

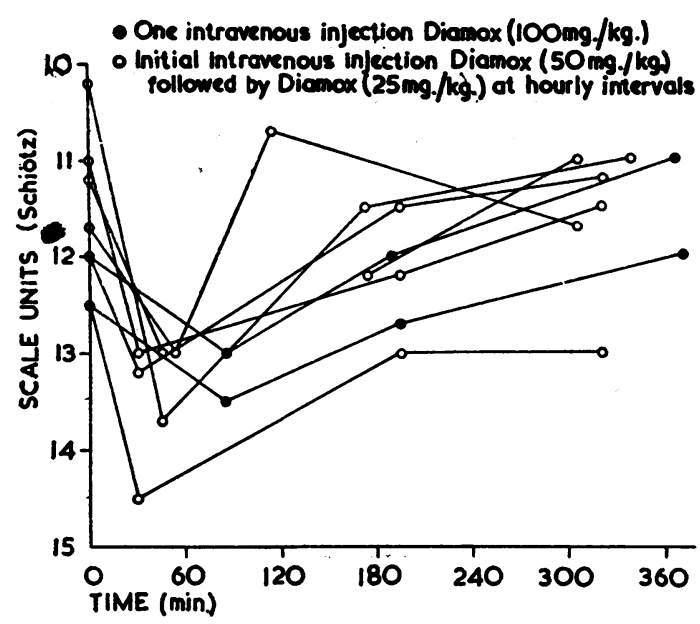

Fig. 6.-Effect of Diamox on intraocular pressure of conscious rabbits. Standard Schiötz X tonometer used to measure intra-ocular pressure.

Ammonium chloride given orally $(270 \mathrm{mg} . / \mathrm{kg}$. body weight) to conscious rabbits also caused a decrease in the intra-ocular pressure corresponding to a change of 2 to 3 divisions on the Schiötz scale. In contrast to the effect of Diamox, the intra-ocular pressure remained low over the experimental period of $5 \mathrm{hrs}$. Attempts to confirm this hypotensive action of ammonium chloride by the manometric technique were not successful owing to its action on the blood pressure when injected intravenously.

\section{Discussion}

In assessing how Diamox influences the composition of the aqueous humour and intra-ocular dynamics several observations merit special mention. First, Diamox caused a reduction in $p \mathrm{H}$ and also in the concen- 
trations of bicarbonate in the aqueous humour and the blood, but only a temporary reduction in the ratio of the concentrations of bicarbonate between the aqueous humour and the blood. Secondly, there was a rapid but only temporary decrease in the rate of flow of the aqueous humour. Thirdly, Diamox neither inhibited the secretion of ascorbic acid across the bloodaqueous barrier nor significantly affected the distribution of sodium between the two fluids. Lastly, there was a rapid and significant fall in the intraocular pressure followed by a partial or complete recovery. It would seem to follow that, in the continued presence of Diamox, there is little or no effect on the intra-ocular dynamics of the normal rabbit eye. At the same time, in confirmation of previous investigations, our experimental results show that Diamox can cause transient changes in the intra-ocular pressure and in the formation of the aqueous humour. For this reason, the animals employed in this study could not be considered resistant to the action of Diamox. These views are not, however, in agreement with the conclusions of Becker (1956) and Becker and Constant (1955); in this discussion the discrepancies may to some extent be resolved.

It now appears well established that in rabbits the concentrations of hydroxyl and bicarbonate ions in the aqueous humour exceed those in the plasma and that the two fluids are not in thermodynamic equilibrium in so far as the distribution of these two ions is concerned. In an ultrafiltrate of plasma, Greene and Power (1931) reported that the concentrations of hydroxyl and bicarbonate ions were approximately 4 per cent. higher than in the plasma water and in agreement with the theoretical van Slyke ratio of 1.04. In studies of the dialysis of horse serum against a solution of salt at $38^{\circ}$ C., Hastings, Salvesen, Sendroy, and van Slyke (1927) reported ratios of 1.13 for the hydroxyl ion and 1.03 for the bicarbonate ion, and concluded that the bicarbonate ion approached more closely to the theoretical van Slyke ratio than chloride, sodium, and hydrogen ions. On this basis the excess of hydroxyl and bicarbonate ions in the aqueous humour above that consistent with passive ultrafiltration or dialysis of the plasma is 20-30 per cent. In absolute amounts the excess of bicarbonate in the aqueous humour was equal to $7 \mathrm{mEq} / \mathrm{kg} \cdot \mathrm{H}_{2} \mathrm{O}$. This exceeds that observed for other ions and is well above that required to account for the hypertonicity of the aqueous humour which is generally agreed not to exceed 2 to $3 \mathrm{mMNaCl} / \mathrm{kg} \cdot \mathrm{H}_{2} \mathrm{O}$. Consequently, the excess bicarbonate must be partially or completely compensated by a reciprocal deficit of another anion.

The origin of the high concentrations of hydroxyl and bicarbonate ions in the aqueous humour remains unsolved. One explanation that either or both of these ions are secreted across the stromal epithelial barrier of the ciliary process was suggested by Friedenwald, Buschke, and Michel (1943) on the the evidence of the transfer of dyes across the ciliary processes. Friedenwald (1949) postulated that the primary product of the secretory mechanism was the accumulation of hydroxyl ions in the epithelium and 
hydrogen ions in the stroma, and that an excess of bicarbonate ions would accumulate on the epithelial side of the barrier through the reaction of hydroxyl ions with carbonic acid. There is, however, an alternative explanation-that the excess of these ions is dependent on the composition and metabolic activity of the corneal, lens, and retinal tissues. The ions and water constituting the aqueous humour are freely diffusible with those in the cornea across the endothelium. Therefore, in considering the nature of the aqueous humour and its thermodynamic equilibration with the plasma, the membrane-effect acting across the corneal-aqueous barrier cannot be ignored. The extracellular volume of the corneal stroma has a high concentration of indiffusible anions and the concentration of sodium exceeds that in the aqueous humour by some 20 to 30 per cent. (Langham and Taylor, 1956). This membrane-effect would tend to increase the $p \mathrm{H}$ and the concentration of all anions in the aqueous humour of the anterior chamber, above that found in an ultrafiltrate of plasma. Thus, in the presence of this factor, the anatomical complexities of the posterior and anterior chambers the presence of a constant circulation of the aqueous humour, and the low maximal concentration gradient of $1.2 \times 10^{-8} \mathrm{mEq}$ of hydroxyl ion $/ \mathrm{kg} . \mathrm{H}_{2} \mathrm{O}$ between the plasma and the aqueous humour, it might be considered surprising if the hydroxyl ion were in complete thermodynamic equilibrium with the plasma. It is, therefore, of particular interest that Davson and Luck (1956) have shown that the distribution of bicarbonate between the aqueous humour and the plasma varies in different species and that in some animals, including man, the concentration in the aqueous humour is less than that in the plasma.

The effect of Diamox on the $p \mathrm{H}$ and on the concentration of bicarbonate in the plasma is consistent with its recognized action in increasing the $p \mathrm{H}$ and excretion of bicarbonate in the urine. The fall in the concentration of bicarbonate in the plasma of 6 to $8 \mathrm{mEq} / \mathrm{kg}$. $\mathrm{H}_{2} \mathrm{O}$ from an initial mean value of $24 \mathrm{mEq} / \mathrm{kg}$. $\mathrm{H}_{2} \mathrm{O}$ agrees well with similar observations on dogs (Maren and others, 1954) and man (Galdston, 1955). This took place with doses of Diamox of $20 \mathrm{mg}$. $/ \mathrm{kg}$ body weight and was not increased at concentrations of $100 \mathrm{mg} . / \mathrm{kg}$ body weight. The main decrease in the concentration of bicarbonate in the plasma took place within the first 2 hours, although it is interesting to note that at 15 minutes the concentration had not altered significantly (compare Tables I, II, and III). This would seem to indicate that the loss of bicarbonate through the kidney had not reduced the body bicarbonate sufficiently to affect the plasma concentration during this period. It is therefore of special interest that there was in the same 15-minute period an apparent fall in the $p \mathrm{H}$ of the blood and an increase in the arterial $\mathrm{CO}_{2}$ tension. From general physiological principles it is unlikely that Diamox could cause a decrease in the $p \mathrm{H}$ and an increase in the $\mathrm{CO}_{2}$ tension of the blood within $15^{\circ} \mathrm{min}$. Therefore these analyses could reflect changes inthe $p \mathrm{H}$ of the blood at the time of withdrawal. This explanation is supported 
by the calculation that the $p \mathrm{H}$ of the blood equals that in untreated animals if the $\mathrm{CO}_{2}$ tension is assumed to equal that in the aqueous humour.

In the same initial period of 15 minutes the $p \mathrm{H}$ decreased and the $\mathrm{CO}_{2}$ tension of the aqueous humour increased and, in addition, there was a marked decrease in the concentration of bicarbonate. This could well be due to the increased acidity, for the very low buffering power of the aqueous humour is determined almost completely by its bicarbonate content. On the other hand, it could be argued that the decrease is consistent with a hypothetical inhibitory effect of Diamox on a process of secretion of bicarbonate into the aqueous humour. This, however, appears unlikely, since the excess concentration of bicarbonate in the aqueous humour became re-established within 2 to 3 hours in spite of further injections of Diamox.

Thus, although Diamox caused a temporary disturbance of the normal distribution ratio for bicarbonate, the excess of both hydroxyl and bicarbonate ions in conditions of steady-state were proportionately the same as in normal untreated rabbits. It is therefore evident that Diamox, even though it may completely inhibit the carbonic anhydrase activity in the ciliary processes (Green, Capper, Bocher, and Leopold, 1954), does not alter the normal distribution ratios of these ions. Consequently, it is unlikely that carbonic anhydrase activity in the eye is essential to the accumulation of excess bicarbonate in the aqueous humour.

The report of Becker (1956) that the normal distribution of bicarbonate between the aqueous humour and the blood is altered by Diamox hinges on the fact that he did not detect a decrease in the concentration of bicarbonate in the plasma of rabbits given Diamox during a period of 6 hours. His results on the aqueous humour, which were determined in a similar manner to those described in this paper, are in accord with the present observations; and this strengthens our opinion that a similar agreement would have been obtained in the plasma analyses had the more detailed procedure used in this study been followed. It is to be remembered that a decrease in the concentration of bicarbonate in the plasma of animals given Diamox for several hours agrees with the observations of many workers in this field (e.g. Maren and others, 1954; Galdston, 1955), and indeed constitutes the accepted mode of action of Diamox in increasing the renal excretion of sodium bicarbonate (Berliner, 1951).

The analyses of the sodium content of the aqueous humour show that the marked loss of bicarbonate immediately after giving Diamox is not accompanied by an equivalent decrease in the concentration of the main cation, sodium. It would seem that there was no marked reduction in the rate of transfer of sodium into the eye either during this period or in conditions approaching steady-state. This conclusion agrees with the findings of Kinsey, Camacho, Cavanaugh, and Constant (1955), who reported that Diamox did not affect the turnover rate of sodium in the aqueous humour. 
The constancy of the steady-state ratios for the sodium, hydroxyl, and bicarbonate ions lends support to the experimental evidence that the intraocular dynamics remain essentially unchanged after the administration of Diamox.

The transfer of ascorbic acid across the blood-aqueous barrier was studied in the belief that, if Diamox affected the secretory mechanism in the manner postulated by Friedenwald (1955a, b), the transfer of ascorbic acid would presumably also be modified. Friedenwald (1955a) suggested that carbonic anhydrase acts by facilitating the neutralization of hydroxyl ions on the epithelial side and hydrogen ions on the stromal side of the ciliary process. In the former area the excess of hydroxyl ions would react with carbonic acid to form bicarbonate, and in the latter area hydrogen ions would react with bicarbonate to form carbonic acid. Diamox, it was postulated, would slow down these reactions of neutralization and lead to a change in $p \mathrm{H}$ which could inhibit the enzymes necessary for the secretory process. Now ascorbic acid is the only compound which is universally agreed to be secreted across the ciliary processes, and to it has been ascribed a cardinal role in the secretory mechanism (Friedenwald, 1949). It is therefore of some significance that the transfer of this compound across the bloodaqueous barrier underwent no significant change in the presence of Diamox. It is true that the small increase in the concentration of ascorbic acid in the aqueous humour of animals given Diamox 3 hours previously is consistent with an increase in the rate of secretion; but, on the other hand, it may be more simply ascribed to the transient decrease in the rate of flow of the aqueous humour during the first 1 or 2 hours.

The results with ascorbic acid are in general agreement with those reported by Becker (1956) in nephrectomized rabbits. In this paper he analysed the concentration of ascorbic acid in the posterior and anterior chambers and in the plasma, and used these values to derive information about the rate of flow of the aqueous humour. This approach was based on the equations of Kinsey and Palm (1955) in which the rate of accumulation of a substance in the anterior chamber was expressed in the form

$$
\frac{d C_{a q}}{d t}=K_{f}\left(C_{\pi}-C_{a}\right)+K_{d}\left(C_{p}-C_{a}\right),
$$

Where $C_{\pi}, C_{a}$, and $C_{p}$ represent, respectively, the momentary concentrations of the test substance in the fluid passing through the pupil $\left.{ }_{\pi}\right)$, in the anterior chamber $(a)$, and in the plasma $(p) . \quad K_{f}$ represents the rate of flow per minute as a fraction of the volume of the anterior chamber; $K_{d}$ represents the corresponding rate of diffusional exchange between the anterior chamber and the plasma. In conditions of steady-state,

$$
\frac{d C_{a}}{d_{t}}=\text { zero, and } \frac{K_{f}}{K_{d}}=\frac{C_{a}-C_{p}}{C_{\pi}-C_{a}} \text {. }
$$


Using both equations, Becker found that, in animals given Diamox, the rate flow of the aqueous humour was depressed 60 per cent. in conditions of steady-state.

This conclusion is in apparent disagreement with the observations recorded in the present study that the rate of flow is unchanged in conditions of steadystate. It should, however, be pointed out that the experiments of Becker were carried out on nephrectomized rabbits; the conclusion that Diamox inhibits the rate of flow of the aqueous humour by 60 per cent. in normal animals rests on the assumption that rabbits in which the renal arteries have been ligated 18 to 24 hours previously are normal. This, however, is not so, for the present experiments show that changes occurred in the composition of the aqueous humour, in the permeability of the blood-aqueous barrier, and in the intra-ocular pressure of rabbits after ligation of the renal arteries. Furthermore, Diamox caused an irreversible lowering of the intra-ocular pressure in these animals.

There is general agreement that fluorescein can be used as a test substance to measure relative changes in the rate of flow or in the formation of the aqueous humour (Linnér and Friedenwald, 1954; Becker, 1955b; Langham and Wood, 1956). The experimental results in this paper showed that the time taken for fluorescein to pass from the bloodstream and into the anterior chamber via the posterior chamber increased by approximately 50 per cent. 14 minutes after the administration of Diamox, and that this increase in the time of flow remained high for at least 1 to 2 hours. Subsequently, however, there was a return of the flow-time to normal in spite of the administration of further amounts of Diamox. An increase in the flow-time of 100 per cent. would be equivalent to a decrease in the rate of flow of at least 50 per cent., and the observed increase of 50 per cent. in appearance time would be equivalent to a decrease in the rate of flow of approximately $20-25$ per cent. The changes in the rate of flow of the aqueous humour after the administration of Diamox is of interest, in that the initial decrease in the rate of flow occurred at the same time as the loss of bicarbonate in the aqueous humour. Furthermore, the recovery of flow to normal was concurrent with the return of the bicarbonate distribution ratio to normal. Presumably the action of Diamox in decreasing the rate of flow of the aqueous humour is associated with a disturbance of the normal osmotic balance between the aqueous humour and the blood, and these results are consistent with the view that the loss of bicarbonate in the aqueous humour was responsible for the temporarily decreased rate of formation.

The variation observed in this study in the level of the intra-ocular pressure in normal rabbits given Diamox is in agreement with the results of previous investigations. The change was rapid and reached a maximum within 30 to 60 minutes. Becker (1955a) and Becker and Constant (1955) reported that the normal intra-ocular pressure in rabbits fell rapidly and reached a minimal value within 20 to 40 minutes and that in some rabbits the intra- 
ocular pressure returned to normal within 2 hours. By the tonographic technique of Grant (1950), they found evidence that during this time there was in increase in the resistance to outflow which tended to minimize the full action of the Diamox. This increase in the resistance to outflow cannot however explain the return of the intra-ocular dynamics to normal in conditions of steady-state, for if the rate of formation is unchanged, an increase in the resistance to outflow would cause the intra-ocular pressure to rise above its normal value. It is therefore likely that any change in the resistance to outflow takes place only when the intra-ocular pressure and the rate of formation of the aqueous are depressed during the period immediately following the administration of Diamox.

The conclusion emerging from these studies-that the intra-ocular dynamics of the normal eye are almost, if not completely, undisturbed by Diamox in conditions of steady-state-is not inconsistent with the wellproven fact that, in similar conditions, the intra-ocular pressure is decreased and controlled in the glaucomatous eye. It is reasonable to assume that the immediate action of Diamox on the body is basically the same, and that the essential difference in the final equilibrium is determined by the different properties of the hypertensive eye. Theoretically, there are several factors which could make the eye with a high intra-ocular tension react more dramatically than the normal eye. First, there is the obvious reason that a given change in flow will lead to a greater absolute fall in the intra-ocular pressure if the initial pressure is high. Secondly, there is the possibility that homeostatic mechanisms are operating in the eye with a normal intra-ocular pressure and not in the eye with a pressure above a certain critical level. In this case, Diamox may reduce the pressure sufficiently to the level at which the homeostatic mechanism acts. Thirdly, it is possible that the relative contributions of filtration and osmotic pressures in the maintenance of the flow of the aqueous humour are not the same in the two cases. In this event Diamox could affect the rate of formation of the aqueous humour in the normal and abnormal eye disproportionately.

There are few reports of the action of Diamox on normal human eyes. Grant and Trotter (1954) observed that Diamox in doses used clinically did not decrease the intra-ocular pressure of normal eyes more than 1 or $2 \mathrm{~mm} . \mathrm{Hg}$, and they also made the interesting observation that in glaucomatous eyes which were at comparable initial pressures due to the action of miotic drugs, the change in intra-ocular pressure after Diamox was only $3 \mathrm{~mm}$. in four out of five eyes. These results referred to conditions of steady-state. Similar observations on normal and glaucomatous human eyes have been reported by Campbell, Tonks, and Jones (1956). The lack of change in the intraocular pressure of these subjects contrasts with the observations of Becker (1955c) on fifteen normal eyes of ten subjects given a high dosage of Diamox by mouth. Approximately 3 hours after giving $500 \mathrm{mg}$. Diamox by mouth the intra-ocular pressure was found to be decreased from a mean value of 
17.6 to $14.6 \mathrm{~mm}$. $\mathrm{Hg}$, and the rate of flow to be decreased by a mean value of 55 per cent. as measured by the tonographic technique.

The assessment of how and to what extent Diamox acts on the eye is handicapped by our lack of knowledge of the contribution that secretion and the hypertonicity of the aqueous humour play in the movement of water through the anterior chamber. It is widely accepted that the osmotic pressure of the aqueous humour is 1 to 2 per cent. higher than that of the blood (Benham, Duke-Elder, and Hodgson, 1938; Roepke and Hetherington, 1940; Davson, Duke-Elder, and Maurice, 1949; Bárány, 1947; Kinsey, 1951). This osmotic excess is equivalent to a hydrostatic pressure of $100-200 \mathrm{~mm}$. Hg. and would mean that the hydrostatic pressures acting across the bloodaqueous barrier contributes in a minor way to the movement of fluid through the eye. On the other hand, the estimate of the osmotic pressure of the aqueous humour may be high, since these determinations were made at temperatures below $37.5^{\circ} \mathrm{C}$. Now the $p \mathrm{H}$-temperature coefficient is not the same for blood and for the aqueous humour and, as a consequence, a given decrease in temperature will disturb the two fluids disproportionately. In this connexion, the studies of Ingraham, Lombard, and Visscher (1933) have shown that the distribution ratio for sodium and potassium ions between plasma and its ultrafiltrate decreases with an increased $p \mathrm{H}$; the value for sodium fell from 0.928 to 0.913 and for potassium from 0.901 to 0.816 when the $p \mathrm{H}$ increased from $7 \cdot 0$ to $7 \cdot 70$. Consequently, in determinations of the relative osmotic activity of these two fluids at temperatures below that of the body, an error is introduced which causes an increase in the osmotic pressure of the aqueous humour in relation to that of the blood.

In bringing together these findings on normal and glaucomatous eyes, the evidence is consistent with the view that Diamox modifies the osmotic balance between the blood and the aqueous humour independently of its renal action. The mechanism remains unsolved, but would appear to be related to an increased acidity in the eye. In animals, however, this increased acidity relative to that of the blood was only temporary. This could have been due to a disproportionate inhibition of carbonic anhydrase activity in different regions of the eye through a slow penetration of Diamox, or it could have reflected the ability of the eye to reassert the normal concentration ratios of hydroxyl and bicarbonate ions between the aqueous humour and the blood. Apart from the changes in the concentration of bicarbonate in the aqueous humour immediately after giving Diamox, no evidence has been found to support the view that Diamox inhibits the secretion of bicarbonate into the eye. The possibility that Diamox directly or indirectly inhibits the active transport of some other ion such as sodium or chloride cannot be answered from this study. 


\section{Summary}

(1) The $p \mathrm{H}$ and the concentration of total carbon dioxide in the aqueous humour and in the arterial blood of normal rabbits have been determined. The $p \mathrm{H}$ temperature coefficient was determined separately and found to be $0.0147 \pm 0.0002$ and $0.0064 \pm 0.00025 p \mathrm{H}$ units per ${ }^{\circ} \mathrm{C}$. for the blood and the aqueous humour respectively. The $p \mathrm{H}$ and the concentration of bicarbonate in the aqueous humour exceeded those in the blood and the calculated values of the $p \mathrm{CO}_{2}$ tensions in the two fluids were found to be equal.

(2) The composition of the aqueous humour and the blood has been analysed at varying times after an injection of Diamox. A rapid fall in the $p \mathrm{H}$ and a concurrent increase in the $\mathrm{CO}_{2}$ tension in the two fluids was observed. At the same time there was a decrease in the concentration of bicarbonate in the aqueous humour and a temporary decrease in the normal excess of bicarbonate. In conditions of steady-state, however, the distribution ratio $\left(C_{a q} / C_{p l}\right)$ was equal to that in control animals.

(3) Ammonium chloride, given in amounts that produced a marked acidosis, resulted in a prolonged decrease in the excess of bicarbonate in the aqueous humour. Ligation of the renal arteries induced a state of progressive acidosis, but left the normal distribution ratio for bicarbonate unchanged. The administration of Diamox to these animals resulted in a further increase in the $\mathrm{CO}_{2}$ tension and a decrease in the $p \mathrm{H}$ of the aqueous humour.

(4) Analysis of the concentrations of sodium in the aqueous humour and the blood after administration of Diamox showed that the initial fall of approximately $6 \mathrm{mEq} \mathrm{HCO}_{3} / \mathrm{kg}$. $\mathrm{H}_{2} \mathrm{O}$ in the aqueous humour was not accompanied by any significant change in the normal distribution ratio of the sodium ion.

(5) The effect of Diamox and ammonium chloride on the secretion of ascorbic acid across the blood-aqueous barrier has been studied. Both compounds led to an increase in the concentration of ascorbic acid in the aqueous humour compatible with a decrease in the rate of flow of the aqueous humour. It may be concluded that neither compound inhibited secretion of ascorbic acid.

(6) The circulation of the aqueous humour and its rate of flow in rabbits given Diamox or ammonium chloride have been studied using fluorescein as a test substance. The time taken for fluorescein to pass from the bloodstream through the posterior chamber to the pupillary area immediately in front of the lens was $238 \pm 23$ (11) seconds; 1 hour after the administration of Diamox this increased to $348 \pm 21$ (9) seconds. In animals maintained on Diamox for 6 hours, the appearance-times were normal. Ammonium chloride also led to an increase in the fluorescein appearance-time which 
was maintained over several hours. It is concluded that Diamox temporarily reduced the rate of flow of the aqueous humour.

(7) Intra-ocular pressure observations, using both the manometric and the tonometric methods of measurements, are reported. In confirmation of other investigations, the intra-ocular pressure was found to fall rapidly after giving Diamox and then to increase toward normal. Ammonium chloride in doses that gave frank acidosis caused a more prolonged lowering of the intra-ocular pressure.

(8) It is concluded from these studies that the continued presence of Diamox gives rise to little or no effect on the intra-ocular dynamics of the normal rabbit eye. It is also suggested that the temporary reduction in the intra-ocular pressure, the rate of formation of the aqueous humour, and the excess of bicarbonate in the aqueous humour immediately following the administration of Diamox are associated with the action of this substance in inducing a rapid fall in the $p \mathrm{H}$ of the aqueous humour.

The authors are indebted to Sir Stewart Duke-Elder for his constant interest and encouragement and to the Medical Research Council for defraying the expense of this research.

\section{REFERENCES}

BÁrÁNy, E. H. (1947). Acta physiol. scand., 13, 81.

and LANGHAM, M. E. (1955). Ibid., 34, 99.

BeCKer, B. (1955a). Amer. J. Ophthal., 39, No. 2, pt. 2, p. 177.

- (1955b). Ibid., 40, No. 5, pt. 2, p. 129.

- (1955c). "Acta XVII Conc. Ophthal., 1954, Canada, U.S.A.", vol. 3, p. 1557.

(1956). Amer. J. Ophthal., 41, 522.

- and Constant, M. A. (1955). A.M.A. Arch. Ophthal., 54, 321.

Benham, G. H., Duke-Elder, S., and Hodgson, T. H. (1938). J. Physiol. (Lond.), $92,355$.

BERLINER, R. W. (1951). "Renal Function". Trans. Third Conf. New York, Josiah Macy, Jr. Foundation, 1951, p. 176.

Campbell, D. A., Tonks, E. L., and Jones, M. (1956). British Journal of Ophthalmology, $40,283$.

Cranston, W. I., Sanderson, P. H., and Stapleton, T. (1955). J. Physiol. (Lond.), 129, 71 P.

Davson, H., Duke-Elder, S., and Maurice, D. M. (1949). Ibid., 109, 32.

and LUCK, C. P. (1956). Ibid., 132, 454.

Friedenwald, J. S. (1949). Amer.J. Ophthal., 32, No. 6, pt. 2, p. 9.

- (1955a). Ibid., 39, No. 4, pt. 2, p. 59.

(1955b). Ibid., 40, No. 5, pt. 2, p. 139.

- and BECKER, B. (1955). A.M.A. Arch. Ophthal., 54, 799.

-, BUSCHKE, W., and MiChEL, H. O. (1943). Ibid., $29,535$.

- and STIEHLER, R. D. (1938). Ibid., 20, 761.

Galdston, M. (1955). Amer. J. Med., 19, 516.

Gloster, J. (1955). J. Physiol. (Lond.), 128, 77P.

and Perkins, E. S. (1955). British Journal of Ophthalmology, 39, 647.

Grant, W. M. (1950). Arch. Ophthal. (Chicago), 44, 204.

- and TrotTER, R. R. (1954). Ibid., 51, 735.

Greaves, D. P., and Perkins, E. S. (1952). British Journal of Ophthalmology, 36, 258.

Green, H., Bocher, C. A., and LeOPOLD, I. H. (1955). A.M.A. Arch. Ophthal., 53, 472.

-, CAPPER, S. A., Bocher, C. A., and LeOPOLD, I. H. (1954). Ibid., 52, 758.

Greene, C. H., and Power, M. H. (1931). J. biol. Chem., 91, 183.

Haldane, J. B. S. (1921). J. Physiol. (Lond.), 55, 265.

, Linder, G. C., Hilton, R., and Fraser, F. R. (1928). I Ibid., 65, 412.

Hastings, A. B., SALVESen, H. A., Sendroy, J., Jr., and VAN SlYKe, D. D. (1927). J.gen. Physiol. 8, 701.

IngrahaM, R. C., Lombard, Ć., and Visscher, M. B. (1933. J. gen. Physiol., 16, 337.

KAUTH, H. S., and SOMMER, H. (1953). Biol. Zbl., 72, 196. 
KINSEY, V. E. (1947). Amer. J. Ophthal., 30, 1262.

(1950). Arch. Ophthal. (Chicago), 44, 215.

(1951). J. gen. Physiol., 34, 389.

, Camacho, E., Cavanaugh, G. A., and Constant, M. (1955). Amer. J. Ophthal., 40, November, pt. 2, p. 147.

- and Palm, E. (1955). A.M.A. Arch. Ophthal., 53, 330.

KoRNBlueth, W., and LiNNÉR, E. (1955). Ibid., 54, 717.

Langham, M. E. (1950). J. Physiol. (Lond.), 111, 388.

(1955a). In "Glaucoma", ed. S. Duke-Elder, p. 45. Blackwell, Oxford.

(1955b). J. Physiol. (Lond.), 130, 1.

and LEE, P. M. (1955a). Trans. ophthal. Soc. U.K., 75, 229.

- and - (1955b). J. Physiol. (Lond.), 130, 27P.

- and - (1955c). Ibid., 130, 27P.

and TAYLOR, I. S. (1956). British Journal of Ophthalmology, 40, 321.

and Wood, P. (1956). J. Physiol. (Lond.), 132, 55P.

and WYBAR, K. C. (1954). British Journal of Ophthalmology, 38, 52.

LINNÉR, E. (1952). Acta physiol. scand., 26, Suppl. 1, 1.

and FrIEDENWALD, J. S. (1954). Report presented to Wilmer Residents Meeting, April.

Maren, T. H., and WaDsworth, B. C. (1954). Fed. Proc., 13, 383.

MARE, T, Yale, E. K., and Alonso, L. G. (1954). Bull.Johns Hopk. Hosp., 95, 277.

Pierce, H. F., Friedenwald, J. S., and Freeman, D. (1933). Amer. J. Physiol., 104, 553.

RoEPKe, R. R., and Hetherington, W. A. (1940). Ibid., 130, 340.

Rosenthal, T. B. (1948). J. biol. Chem., 173, 25.

Ross, E. J. (1951). J. Physiol. (Lond.), 112, 229.

SHOHL, A. T., and KarelrTz, S. (1926). J. biol. Chem., 71, 119.

VAN SLYKE, D. D. (1926). "Factors affecting the Distribution of Electrolytes, Water, and Gases in the Animal Body". Lippincott, Philadelphia.

- and NeILL, J. M. (1924). J. biol, Chem., 61, 523.

and SENDROY, J., Jr. (1928). Ibid., 79, 781.

, HASTINGS, A. B., and NeILL, J. M. (1928). Ibid., 78, 765.

von SallmanN, L., and Grand, J. di (1946). Arch. Ophthal. (Chicago), 35, 643.

WARBURG, E. J. (1922). Biochem. J., 16, 153.

Wistrand, P. J. (1951). Acta physiol. scand., 24, 144. 